\title{
Economic Modelling of the Delay in Passing the Petroleum Industry Bill in Nigeria and Its Impact on Deep Offshore Investments and Government Take Statistics
}

Oghenerume Ogolo ( $\sim$ oghenerume.ogolo@nileuniversity.edu.ng )

African University of Science and Technology https://orcid.org/0000-0001-9710-345X

Petrus Nzerem

Nile University of Nigeria

\section{Research}

Keywords: Petroleum Industry Bill, Economic Modelling, Deep Offshore, Government Take, Production Sharing Contract, Fiscal Terms

Posted Date: November 30th, 2020

DOI: https://doi.org/10.21203/rs.3.rs-113385/v1

License: (c) (i) This work is licensed under a Creative Commons Attribution 4.0 International License.

Read Full License 


\section{Abstract}

The petroleum industry bill (PIB) in Nigeria aims to reform the petroleum sector of the country and increase government revenue from petroleum investments. Despite the benefits the bill offers to the country, its passage has suffered several setbacks. This research therefore studied the impact of the delay in passing the bill on deep offshore investments. Economic models were built using the fiscal terms in PIB 2009 and 1993 production sharing contract (PSC) arrangement to evaluate the impact of the bill. The model with the 1993 PSC fiscal terms was adjusted to capture the delay in passing the bill. The bill was assumed to be passed on a yearly basis for 10 years (2010 to 2019). The impact of the delay in passing the bill based on the reserve portfolio of firms in the deep offshore region of the country was also evaluated. The delay in passing the PIB reduced the government take. It was seen that for the nonpassage of the bill, the government lost about $\$ 1227.2$ MM. When the bill was passed in 2019, the government had been losing about $\$ 11.843 \mathrm{MM}$ on a yearly basis due to the delay in passing the bill.

\section{Introduction}

The dynamics of attracting investments in the exploration and production of petroleum in any oil province have gone beyond the ease of producing petroleum and geological constraints (lledare 2010; Onwuka et al. 2012). It now depends mostly on the attractiveness of a Nation's petroleum fiscal system (Iledare 2010; Onwuka et al. 2012; Dongkun and Na, 2010; Kazi Beyesa, 2018). The petroleum fiscal systems defines the relationship between the host government and the contractor, how contractor's will earn revenues from investment and what percentage of revenues accrues to the host government (Echendu et al. 2015; Farimani et al. 2020; Ghandi and Cynthia Lin 2012; lledare 2004; Johnston 1994; Johnston 2003; Johnston et al. 2008; Lawal, 2014; Ogolo et al. 2020). A progressive, stable and dynamic fiscal system will ensure the attractiveness of a fiscal regime (lledare 2004).

For over a decade, Nigeria has been trying to reform her petroleum sector by taking actions to enact the petroleum industry bill (PIB) as an Act of the National Assembly but the bill has faced several setbacks. In 2008, the Oil and Gas Implementation Committee submitted a report that contains the legislation of the PIB to the government. The report was used to draft the PIB (lledare 2010; Onwuka et al. 2012). The bill was sent to the National Assembly of the Federal Republic of Nigeria in 2009 by the then President of Nigeria (lledare 2010). The bill stipulates operational strategies and guidelines for the promotion of Nigeria's prominence in the global energy landscape. It was aimed also at increasing government's revenue from petroleum investments (Iledare 2010). It also aligns the petroleum sector with global best practice, promoting transparency and good governance in the sector. The bill defines and distributes responsibilities to government institutions designed to regulate, make policy and manage the operational and commercial aspect of the industry (lledare 2010). The bill is progressive and dynamic in nature.

Before the emergence of the PIB, in theory, there have been three different production sharing contracts (PSC) arrangements in Nigeria with unique fiscal terms (Echendu and lledare 2014). There are the 1993 PSC, 2000 PSC and 2005 PSC. The 1993 PSC was more progressive in nature and it stipulates a cost 
recovery option of $100 \%$ and zero royalty payments for investment located beyond a water depth of $1000 \mathrm{~m}$. The 2000 PSC had the introduction of VAT included as part of its fiscal terms and the 2005 PSC had a cost recovery option of $80 \%$ (Echendu and lledare 2016). Though the PIB 2009 had a cost recovery option of $70 \%$ but it has a dynamic royalty instrument that slides based on the production capacity of a firm and oil price.

lledare (2010) evaluated the economic impact of the PIB 2009 on the profitability of investments in the production of oil in the offshore region of Nigeria. He said that the government take statistics could be as high as $91 \%$. The unit technical cost for the investment he considered was $\$ 24.29$ per barrel. The investment had a contractor's and host government net present value of \$92.29 MM and \$937.83 MM. The cumulative oil produced from the field was $100 \mathrm{MMbbls}$. Oyekunle (2011) also investigated the impact of the PIB 2009 on deep water investment economics. He found out that the petroleum industry bill will increase government revenue from investments in the deep offshore region. Governments could have a $50 \%$ chance of having a take statistics between $88 \%$ and $91 \%$.

Onwuka et al. (2012) evaluated the impact of depreciation methods and decline curve patterns on the economics of deep water investments in Nigeria using the fiscal terms in the 2005 PSC and PIB 2009. They observed that the exponential decline curve technique that is said to be reserved gave the highest net present value, internal rate of return, growth rate of return and contractor's take statistics. This occurred because all the decline curve techniques used were subjected to the same time period. But they found that the unit of production technique of depreciation gave the most favourable profitability metrics for the PIB 2009 while the straight line depreciation technique gave the most favourable metrics for the 2005 PSC. The government take obtained from the PIB 2009 was higher than the government take obtained from the 2005 PSC.

Sadly, despite the advantages and benefits the PIB 2009 offered to the country, it was not passed as an Act after going through many public hearings by different committees of the National Assembly (Echendu and lledare, 2016). In 2012, a new version of the bill emerged known as the authentic PIB (PIB 2012) (Echendu and lledare 2016). The provisions in the PIB 2012 were drawn extensively from PIB 2009. In the PIB 2012, the payments of fees and royalties were made as a regulatory provision unlike the PIB 2009 that states that, there were to be determined legislatively (Echendu and Iledare 2016). Due to the desire to make the PIB problem focused and ease its passage as an Act, it was broken down into four different bills (Oyekunle 2011). The fiscal terms used in drafting the PIB were incorporated into a new bill called the Petroleum Industry Fiscal Bill (PIFB) with adjustment in some of the fiscal terms. The national hydrocarbon tax and corporate income tax that replaces the petroleum profit tax in the PIB 2009 and PIB 2012 were also adopted in the PIFB.

The emergence of the PIB as a means to reform the petroleum sector in Nigeria brought a sigh of hope to Nigerians and major stake holders of the petroleum industry. But the delay in passing the bill has a major impact in the conduct of activities and revenues generated from the industry. Many research efforts have been made towards evaluating the fiscal provisions in the PIB 2009 and subsequent modifications made 
to the bill. There has not been a research that considered the economic impact of the delay in passing the bill using the fiscal arrangements contained in the bill. This research therefore considers the economic modelling of the delay in passing the PIB and its impact on deep offshore investments and government take statistics.

\section{Methodology}

Cash flow modelling using spreadsheet is one of the tools used to evaluate the impact of a fiscal regime on investments in the exploration and production of petroleum (Echendu and lledare 2014; Hao and Kaiser 2010; Nyoor et al. 2019; Ogolo 2020). This technique was adopted in this research. The production data from a typical deep offshore field was used as the source of revenue for the investments. The fiscal terms embedded in the 1993 PSC and the PIB 2009 were used to determine the net cash flow for the investment. The delay in passing the PIB 2009 was also captured in the models to study the economic implication of the delay in passing the PIB.

\subsection{Field Production Determination}

The field of study is a typical deep offshore field in the Niger Delta. The exponential decline method was adopted to forecast the annual production from the field (Hao and Kaiser 2010; Jahn et al. 2008; Mian 2002; Ogolo 2020; Temizel et al. 2019). Exploration work commenced in the field in 1996 and production of the field began at the end of 1999 with an initial production rate of $6,000 \mathrm{bbl} /$ day. The peak period was three years beginning in 2005 before production began to decline at a rate of $15 \%$. The peak production rate was $81,770 \mathrm{bbl} /$ day. The field production life was 20 years. Equation 1 and equation 2 were used to forecast the daily production rate and annual production from the field. The cumulative production of the field was calculated using equation 3 .

$$
\begin{array}{ll}
q_{(t)}=\frac{q_{i}}{(1+b a t)^{\frac{1}{b}}} & \text { Equation 1 } \\
q_{(t)}=q_{i} e^{-a t} & \text { Equation 2 } \\
Q_{(t)}=\frac{q_{i}-q_{t}}{a} & \text { Equation 3 }
\end{array}
$$

Where 
$\mathrm{q}_{\mathrm{i}}=$ instantaneous production rate

$\mathrm{q}_{\mathrm{t}}=$ production rate at time $\mathrm{t}$

$b=$ decline exponent

$\mathrm{a}=$ decline rate

$\mathrm{t}=$ time

$\mathrm{Q}_{\mathrm{t}}=$ Cumulative production at time $\mathrm{t}$

\subsection{Profitability of Investment under the PIB 2009 and 1993 PSC}

The PIB aims to stabilise the fiscal regime in Nigeria and enable government to accrue more revenue from investments in the production of petroleum. The net cash flow model was used to determine the profitability of investments under the PIB 2009 and 1993 PSC. The fiscal terms for the PIB 2009 and 1993 PSC are stated in Table 1. The field was located in a water depth of $1200 \mathrm{~m}$. Beyond a water depth of $1000 \mathrm{~m}$, no royalty payment is made in the 1993 PSC arrangement but in the PIB 2009, companies are expected to pay royalty based on the royalty scheme specified for that field. The field annual production was used as the source of revenue for the investment. The yearly oil price used was the actual oil price for bonny light crude oil from 2000 to 2019 as shown in Figure 1. This is to enable the actual determination of the economic impact of the PIB 2009 on investment in the deep offshore region of Nigeria.

Exploration of the field began in 1996 and took place for two years with an annual exploratory cost of $\$ 270$ MM. The field development started in 1998 and it was done for two years. \$950 MM and \$1500 MM were spent during the first and second field development year. The operating expenditure was assumed to be $5 \%$ of the capital expenditures. The cost recovery option specified in the 1993 PSC was $100 \%$ while that of the PIB 2009 was $70 \%$. These fiscal terms were incorporated into the economic models that were used to determine the net cash flow of the investment. Other profitability indicators that were determined from the net cash flow include the net present value, the internal rate of return, payout period, unit technical cost, discounted and undiscounted host government and contractors take statistics and frontend loading index.

Table 1: Fiscal Terms in the 1993 PSC and PIB 2009 


\begin{tabular}{|c|c|c|c|c|c|}
\hline \multirow{2}{*}{$\begin{array}{l}\text { Terms } \\
\text { Royalty Rate }\end{array}$} & \multicolumn{2}{|l|}{1993 PSC } & \multicolumn{3}{|l|}{ PIB 2009} \\
\hline & \multirow{2}{*}{$\begin{array}{l}\text { Water Depth } \\
\text { (Metres) }\end{array}$} & \multirow{2}{*}{$\begin{array}{l}\text { Royalty Rate } \\
(\%)\end{array}$} & \multicolumn{3}{|l|}{ Value } \\
\hline & & & Range & $\begin{array}{l}\text { Price } \\
(\$ / b b l)\end{array}$ & $\begin{array}{l}\text { Effective } \\
\text { Royalty Rate } \\
(\%)\end{array}$ \\
\hline & $<=100$ & 18 & up to $\$ 70$ & 70 & 0 \\
\hline & $10-200$ & 16.667 & $\$ 70-\$ 110$ & 110 & 16 \\
\hline & $201-500$ & 12 & $\$ 110-\$ 140$ & 140 & 22 \\
\hline & $501-800$ & 8 & $\$ 140-\$ 170$ & 170 & 25 \\
\hline & & & $>\$ 170$ & 171 & 25 \\
\hline & $801-1000$ & 4 & \multicolumn{3}{|c|}{ Volume (Deep Offshore) } \\
\hline & $>1000$ & 0 & $\begin{array}{l}\text { Production } \\
\text { (Mbbl/day) }\end{array}$ & & $\begin{array}{l}\text { Royalty Rate } \\
\text { (\%) }\end{array}$ \\
\hline & & & $0-50$ & & 5 \\
\hline & & & $50-100$ & & 12.5 \\
\hline & & & $>100$ & & $25 \%$ \\
\hline \multirow[t]{7}{*}{ Profit Oil } & $\begin{array}{l}\text { Cummulative Oil } \\
\text { Production }\end{array}$ & $\begin{array}{l}\text { Contractor's } \\
\text { Profit Oil Share }\end{array}$ & $\begin{array}{l}\text { Cummulati } \\
\text { Production }\end{array}$ & Oil & $\begin{array}{l}\text { Contractor's } \\
\text { Profit Oil } \\
\text { Share }\end{array}$ \\
\hline & (MMBOE) & $(\%)$ & (MMBOE) & & $(\%)$ \\
\hline & $<350$ & 80 & Up to 750 & & 80 \\
\hline & $350-750$ & 65 & $750-1000$ & & 70 \\
\hline & $751-1000$ & 55 & $1000-2000$ & & 60 \\
\hline & $1001-1500$ & 50 & $>2000$ & & Negotiable \\
\hline & $>1500$ & 40 & & & \\
\hline $\begin{array}{l}\text { Cost Recovery } \\
\text { Option }\end{array}$ & $100 \%$ & & $70 \%$ & & \\
\hline Education Tax & \multicolumn{5}{|c|}{$2 \%$ levy on accessible profit. } \\
\hline $\begin{array}{l}\text { Petroleum Profit } \\
\text { Tax }\end{array}$ & $50 \%$ & & & & \\
\hline
\end{tabular}


Bonus Production bonuses and signature bonuses are negotiable

NDDC $\quad 2 \%$ of total budget

Depreciation Straight line depreciation technique for 5 years

\subsubsection{Impact of the Delay in Passing the PIB}

The 1993 PSC model was adjusted to capture the delay in passing the bill for duration of ten years (20102019). The bill was assumed to be passed each year from 2010 to 2019 to determine the resulting implications of the delay in passing the bill on the profitability of the investment. The PIB 2009 and 1993 PSC has different profit oil split ratios that is a function of the reserve or cumulative oil that can be produced from the field. Table 2 shows the different deep water reserve portfolio of a contractor located beyond a water depth of $1000 \mathrm{~m}$ and the host government profit oil split in the PIB 2009 and 1993 PSC. The profit oil split ratio based on the different reserve portfolio as shown in Table 2 were incorporated into the models and the delay in passing bill was also determined to see how the delay in passing the PIB impacts revenues from fields with high amount of reserve.

Table 2: Profit Oil Split for the Host Government

\begin{tabular}{|lll|}
\hline Cumulative Oil Production (bbl) & \multicolumn{2}{l|}{ Profit Oil Split } \\
\cline { 2 - 3 } & 1993 PSC & 2009 PIB \\
\hline 300 & $20 \%$ & $20 \%$ \\
\hline 600 & $35 \%$ & $20 \%$ \\
\hline 900 & $45 \%$ & $30 \%$ \\
\hline 1200 & $50 \%$ & $40 \%$ \\
\hline 1600 & $60 \%$ & $40 \%$ \\
\hline
\end{tabular}

\section{Discussion Of Result}


The field oil production rate is shown in Fig. 2. While the field oil annual production and cumulative production is shown in Fig. 3. The production life of the field was from the end of 1999 to 2019. The field annual production in year 2000 was $2.876 \mathrm{MMbbls}$. The annual production during the peak period was $29.846 \mathrm{MMbbls}$. The cumulative production in the entire life of the field was $300 \mathrm{MMbbls}$. The field had a recovery factor of $20 \%$.

\subsection{Profitability of the Investment under the 1993 PSC and PIB 2009}

Table 3 shows the profitability indicators obtained from the investments under the PIB 2009 and 1993 PSC fiscal arrangement. The NCF of the host government obtained from the investment under the 1993 PSC and 2009 PIB were $\$ 9560.29 \mathrm{MM}$ and $\$ 11138.9 \mathrm{MM}$. While that of the contractor were $\$ 5859.53$ $\mathrm{MM}$ and $\$ 4280.90 \mathrm{MM}$. It can be seen that the host government revenue increased by about $\$ 1578.63$ MM using the PIB 2009 fiscals terms. This was as a result of the introduction of royalty payments for investment beyond a water depth of $1000 \mathrm{~m}$ and a new tax layer. The PIB 2009 requires contractors to pay a corporate income tax of $30 \%$ and national hydrocarbon tax of $30 \%$ for deep offshore investments. Also, under the 1993 PSC, companies do not pay royalty beyond a water depth of $1000 \mathrm{~m}$. But in the PIB, there is a progressive royalty framework. The royalty payment is sliding on both the price of oil and production rate as shown in Table 1. As a result of the increment in the government's revenue under the PIB 2009, the contractor's NCF reduced by $26.94 \%$.

The same observation was also seen in the contractors and host government NPV. The contractors NPV under the 1993 PSC and PIB 2009 were $\$ 421.74 \mathrm{MM}$ and $\$ 57.40 \mathrm{MM}$. While the host government NPV were $\$ 2368.36 \mathrm{MM}$ and $\$ 2732.70$. The NPV of the host government from the investment under the PIB 2009 was higher than what was obtained under the 1993 PSC. The increment was also as a result of the introduction of royalty payments and the new tax layer that was added. The NPV of the contractor reduced due to the increment in government's revenue. The PIB aims to stabilise the fiscal regime and increase government's revenue especially during period of oil windfall. The undiscounted host government take increased from $62-72.24 \%$ and the discounted host government take increased from 84.88-97.94\% for the investment under the PIB 2009. The undiscounted contractor's take reduced from $38-27.76 \%$ and the contractor's discounted take also reduced from $15.12-2.06 \%$.

The internal rate of return (IRR) of the investment under the 1993 PSC and PIB 2009 were $12.14 \%$ and $10.32 \%$. The fiscal arrangement in the PIB 2009 led to a reduction in the IRR of the contractor. This is as a result of the cost recovery limit specified in the PIB 2009. The PIB 2009 stipulates a cost recovery limit of $70 \%$ which made the government to start earning revenues on time reducing the amount of revenue that was supposed to be used to recover the capital cost unlike the case of the 1993 PSC, where the cost recovery limit is $100 \%$. This also affected the payout period of the investment. The payout period for the investment under the 1993 PSC was 10.42 years, while that of the PIB 2009 was 10.58 years. The FLI that defines the front-end loaded nature of a fiscal system was also evaluated using the two fiscal arrangements. Both fiscal arrangements are front-end loaded. It is seen that the PIB 2009 seems to be 
more loaded than the 1993 PSC. The FLI of the investment under the 1993 PSC and PIB 2009 were 0.356 and 0.369 . The PIB 2009 was more loaded because of the cost recovery limit and royalty payment specified for it. The PIB 2009 has a cost recovery limit of $70 \%$ that enables government to start earning revenues on time. The unit technical cost for both investments was $\$ 20$ per barrel of oil. This indicator did not change as a result of the similar production and cost condition imposed on the two models.

Table 3

Profitability Indicators for the 1993 PSC and PIB 2009

\begin{tabular}{|l|llll|}
\hline Metric Systems Measures & \multicolumn{2}{l}{ 1993 PSC } & \multicolumn{3}{l|}{ PIB 2009 } \\
\cline { 2 - 6 } & HG & CT & HG & CT \\
\hline Net Cash Flow (\$MM) & 9560.29 & 5859.53 & 11138.92 & 4280.90 \\
\hline Net Present Value (\$MM) & 2368.36 & 421.74 & 2732.70 & 57.40 \\
\hline Internal Rate of Return & & $12.14 \%$ & & $10.32 \%$ \\
\hline Undiscounted Take & $62.00 \%$ & $38.00 \%$ & $72.24 \%$ & $27.76 \%$ \\
\hline Discounted Take & $84.88 \%$ & $15.12 \%$ & $97.94 \%$ & $2.06 \%$ \\
\hline Payout Period (Years) & & 10.42 & & 10.58 \\
\hline Unit Technical Cost (\$/bbl) & & 20.00 & & 20.00 \\
\hline Front-end Loading Index & & 0.356 & & 0.369 \\
\hline 3.2.2 Delay in Passing the PlB 2009 & &
\end{tabular}

The yearly impact of not passing the bill was measured for duration of 10 years. Figure 4 shows the host government NCF based on the period of delay in passing the bill. The impact of variation in the profit oil split was also studied to understand how the delay in passing the bill could impact profitability of other assets based on their reserve portfolio. The base case model had the least NCF for the host government. This case was the host government take using only the 1993 PSC arrangement. It was observed that the more the delay in passing the bill, the lower the host government take. When the bill was passed in 2010 based on a reserve of $300 \mathrm{MMbbls}$, the host government NCF was $\$ 10787.45 \mathrm{MM}$ and in 2019 , it was \$9603.14 MM. The host government lost about \$1227.2 MM for not passing the bill for the duration considered. An average of $\$ 122.712 \mathrm{MM}$ was lost on yearly basis due to the delay in passing the PIB.

While when the bill was passed in 2015 , the host government NCF was $\$ 9787.56 \mathrm{MM}$. The delay in passing the bill affected the revenue that government was supposed to generate from the investment. This same observation was seen in other profit oil split ratio. It is seen that as the cumulative production increases, the host government revenue increases. Higher reserve will favour more revenue generation in both PSC arrangements. Because as the reserve increases, the profit oil split for the government also increases in accordance with Table 2. Despite this increment, the delay in passing the bill still impacted 
the host government revenue. The host government NCF when the bill was passed in 2010, 2015 and 2019 based on a reserve of 1600 MMbbls were $\$ 13092.07 \mathrm{MM}, \$ 12594.94 \mathrm{MM}$ and $\$ 12461.88 \mathrm{MM}$.

Figure 5 shows the contractor's NCF based on the delay in passing the PIB. The base case model gave the highest contractor's NCF because it is the model built with only the 1993 PSC arrangement. It is seen that the higher the reserve, the lower the contractor's revenue. This occurred because as the reserve increases, the profit oil split for the host government also increases for both fiscal arrangements. But the longer the delay in passing the bill, the more favourable it is to the contractor's. The contractor's NCF for a reserve of $300 \mathrm{MMbbl}$ in year 2010, 2015 and 2019 were $\$ 4632.36, \$ 5632.25$ and $\$ 5816.67$. While the contractor's NCF based for a reserve of $1600 \mathrm{MMbbl}$ in 2010, 2015 and 2019 were $\$ 2327.74$, \$2824.88 and $\$ 2957.94$.

Figure 6 and Figure 7 show the host government and contractor's undiscounted take based on the delay in passing the PIB. The host government undiscounted take for the base model with a reserve of $300 \mathrm{MM}$ was $62 \%$ but it increased to $69.96 \%$ upon passage of the PIB in 2010 . The host government undiscounted take when the bill was passed in 2015 and 2019 were $63.47 \%$ and $62.27 \%$. The host government undiscounted take for the base case model was the least but it increased with the passage of the bill irrespective of the companies reserve portfolio. The earlier the passage of the PIB, the higher the host government take. The contractor's undiscounted take reduced with the passage of the PIB. The more the delay, the higher the contractor's undiscounted take. This is seen in Figure 7. The base case model had the highest undiscounted contractor's take. But it reduced with the passage of the PIB. The higher the contractor's reserve portfolio in the deep offshore region, the lower the contractor's undiscounted take.

Figure 8 shows the internal rate of return for the investment based on the delay in passing the PIB 2009. The internal rate of return for the base case model was the highest but with the passage of the bill, the internal rate of return reduced. The earlier the bill is passed, the lower the rate of return. This is because more revenue is accruing to the host government leading to a reduction in the rate of return of the investment. It was observed that the higher the contractor's reserve portfolio in the deep offshore region, the lower the contractor's internal rate of return. This occurred because of the increment in the government revenue based on the profit oil split ratio. The delay in passing the PIB can also been seen in

the internal rate of return obtained based on the reserve portfolio of a firm. The earlier the bill was passed, the lower the internal rate of return of the investment.

\section{Conclusions}

- The government take obtained from the model developed using the fiscal terms in PIB 2009 was higher than that of the 1993 PSC. This was a result of the new tax layer and the dynamic royalty instrument added to the bill.

- The delay in passing the PIB 2009 affected the government revenue from investment in the deep offshore region. The government lost about \$1227.2 MM for not passing the PIB 2009. This shows that the government lost an average of $\$ 122.72 \mathrm{MM}$ on a yearly basis for not passing the bill on 
assets of such nature in the deep offshore region of the country. When the bill was passed in 2019, the government had been losing about $\$ 11.843 \mathrm{MM}$ on a yearly basis. The earlier the bill was passed as an Act, the higher the revenue the government generated from the investment.

- Despite the achievement of government's motive of passing the bill to generate more revenue, the contractor's revenue was affected. The contractor's NCF reduced from \$5859.53 to \$4632.36 MM when the bill was passed in 2010. The internal rate of return and contractor's take statistics also reduced with the passage of the bill. This was as a result of the early rent extraction embedded in the PIB 2009.

- The higher the reserve portfolio of contractor's in the deep offshore region, the higher the government revenue generated using the PIB 2009 and 1993 PSC fiscal framework. This is as a result of the increment of the profit oil split ratio as the cumulative production increases. Despite the increment in the government's revenue, it was observed that the earlier the bill was passed, the more revenues the government would have generated from assets with high reserve portfolio.

\section{Declarations}

\section{Availability of Data and Materials}

The field used for this study was a hypothetical deep offshore field and the production data of the field was forecasted using exponential decline curve analysis. The fiscal terms used to build the economic models were obtained from the draft 2009 Petroleum Industry Bill and 1993 PSC in Nigeria.

\section{Competing Interests}

The authors declare that they have no known competing financial interests or personal relationships that could have appeared to influence the work reported in this paper.

\section{Funding}

The authors received no specific funding for this research work.

\section{Acknowledgement}

The authors' wishes to thank the management of Nile University of Nigeria for providing the facilities that were used to carry out this research.

\section{Authors Contribution}

The two authors contributed to the drafting of all the sections of this research paper.

\section{Authors Information}

Not Applicable 


\section{References}

1. Central Bank of Nigeria (CBN) (2020) Crude Oil Price. 2020. Retrieved from https://www.cbn.gov.ng/rates/crudeoil.asp?year=2020\&month=5.

2. Dongkun D, Na Y (2010) Assessment of fiscal terms of international petroleum contracts. Petroleum Exploration and Development, 37(6):756-762.

3. Echendu JC, lledare 00 (2016) Progressive Royalty Framework for Oil- and Gas-Development Strategy: Lessons From Nigeria. SPE Econ. \& Manag. 8(03): 68-77. doi:10.2118/174846-pa.

4. Echendu JC, lledare OO, Onwuka El (2015)Comparative Economic-Performance Analysis of Production-Sharing Contracts in Angola, Equatorial Guinea, Gabon, and Nigeria. SPE Econ. \& Manag.; 7(04):157-166. doi:10.2118/162990-pa.

5. Echendu JC, Onwuka El, Iledare 00 (2014) Spreadsheet Modeling and Simulation Analysis of Production Sharing Contract Terms and Instruments in Nigeria. Presented at the SPE Nigeria Annual International Conference and Exhibition, Lagos, 5-7 August. SPE-172389MS http://dx.doi.org/10.2118/172389-MS.

6. Energy Information Agency (EIA) (2020) U.S. Landed Cost for Nigerian Bonny Light Crude Oil. Retrieved from https://www.eia.gov/dnav/pet/hist/LeafHandler.ashx?n=PET\&s=INI1500008\&f=M

7. FM, Mu X, Sahebhonar H, Ali T (2020) An economic analysis of Iranian petroleum contract. Pet. Sci. https://doi.org/10.1007/s12182-020-00486-2.

8. Ghandi A, Cynthia Lin CY (2012) Do Iran's buy-back service contracts lead to optimal production? The case of Soroosh and Nowrooz. Ener. Pol. 42:181-190.doi:10.1016/j.enpol.2011.11.070.

9. Hao H, Kaiser MJ (2010) Modeling China's offshore production sharing contracts using metaanalysis. Pet. Sci. 7: 283-288. https://doi.org/10.1007/s12182-010-0034-8.

10. Iledare 00 (2004) Analyzing the Impact of Petroleum Fiscal Arrangements and Contract Terms on Petroleum E\&P Economics and the Host Government Take. Paper Presented at the SPE Nigeria Annual Technical Conference and Exhibition, Abuja, Nigeria, 2-4 August. SPE-88969-MS. http://dx.doi.org/10.2118/88969-MS.

11. Iledare $O O$ (2010) Evaluating the Impact of Fiscal Provisions in the Draft Petroleum industry Bill on Offshore E\&P Economics and Take Statistics in Nigeria. Paper presented at the 34th Annual SPE International Conference and Exhibition, Tinapa-Calabar, Nigeria, 31 July-7 August. http://dx.doi.org/10.2118/136972-MS.

12. Jahn F, Cook M, Graham M (2008) Hydrocarbon Exploration and Production. Oxford: Elsevier. 2008.

13. Johnston D (1994) International Petroleum Fiscal Systems and Production Sharing Contracts, pp. 25. Tulsa, USA: PennWell Publishing Company.

14. Johnston D (2003) International Exploration Economics, Risk and Contract Analysis. Tulsa: PennWell Books.

15. Johnston D, Johnston D, Rogers T (2008) International Petroleum Taxation. Retrieved from https://www.ipaa.org/wp content/uploads/2017/01/InternatlPetroTaxSupp.pdf. 
16. Kazi BW, Beyeza B (2018) Getting a Good Deal; An Analysis of Uganda's Oil Fiscal Regime. Centre for Research on Peace and Development.

17. Lawal KA (2014)Economics of steam-assisted gravity drainage for the Nigerian Bitumen deposit. J. Pet. Sci. Eng. 116: 28-35.

18. Mian MA (2002) Project Economics and Decision Analysis, Vol. 1. PennWell Corporation.

19. Nyoor B, Oyebimpe A, lledare $O 0$ (2019). The Impact of the Proposed Petroleum Industry Fiscal Bill PIFB, 2018 Tax Scheme on the Economics of Oil Production in Nigeria. SPE Nigeria Annual International Conference and Exhibition. doi:10.2118/198782-ms.

20. Ogolo $O$ (2020) Modification of the Unit Technical Cost Equation for the Accurate Determination of the Cost of Producing a Barrel of Oil in Relation to the Contractor's Revenue. Journal of Petroleum Science and Engineering, https://doi.org/10.1016/j.petrol.2020.108122.

21. Ogolo O, Nzerem P, lledare OO, Okafor SI, Iloegbunam E, Ekeoma PI (2020). Assessing the Impact of Deep Offshore and Inland Basin Production Sharing Contract Amendments on the Economics of Deep Offshore E\&P Assets in Nigeria. SPE Nigeria Annual International Conference and Exhibition. org/10.2118/203741-MS.

22. Onwuka El, Iledare OO, Echendu JC (2012) Evaluating the Impact of Depreciation Methods and Production Decline Patterns on Deepwater Economics: A Case Study of Nigeria. Nigeria Annual International Conference and Exhibition.doi:10.2118/163007-ms

23. Oyekunle AA (2011) Impact of the Petroleum Industry Bill on Deepwater Economics. Nigeria Annual International Conference and Exhibition.doi:10.2118/150774-ms.

24. Temizel C, Tuna T, Oskay MM, Saputelli, LA (2019) Formulas and Calculations for Petroleum Engineering. Burlington: Gulf Professional Publishing.

\section{Figures}




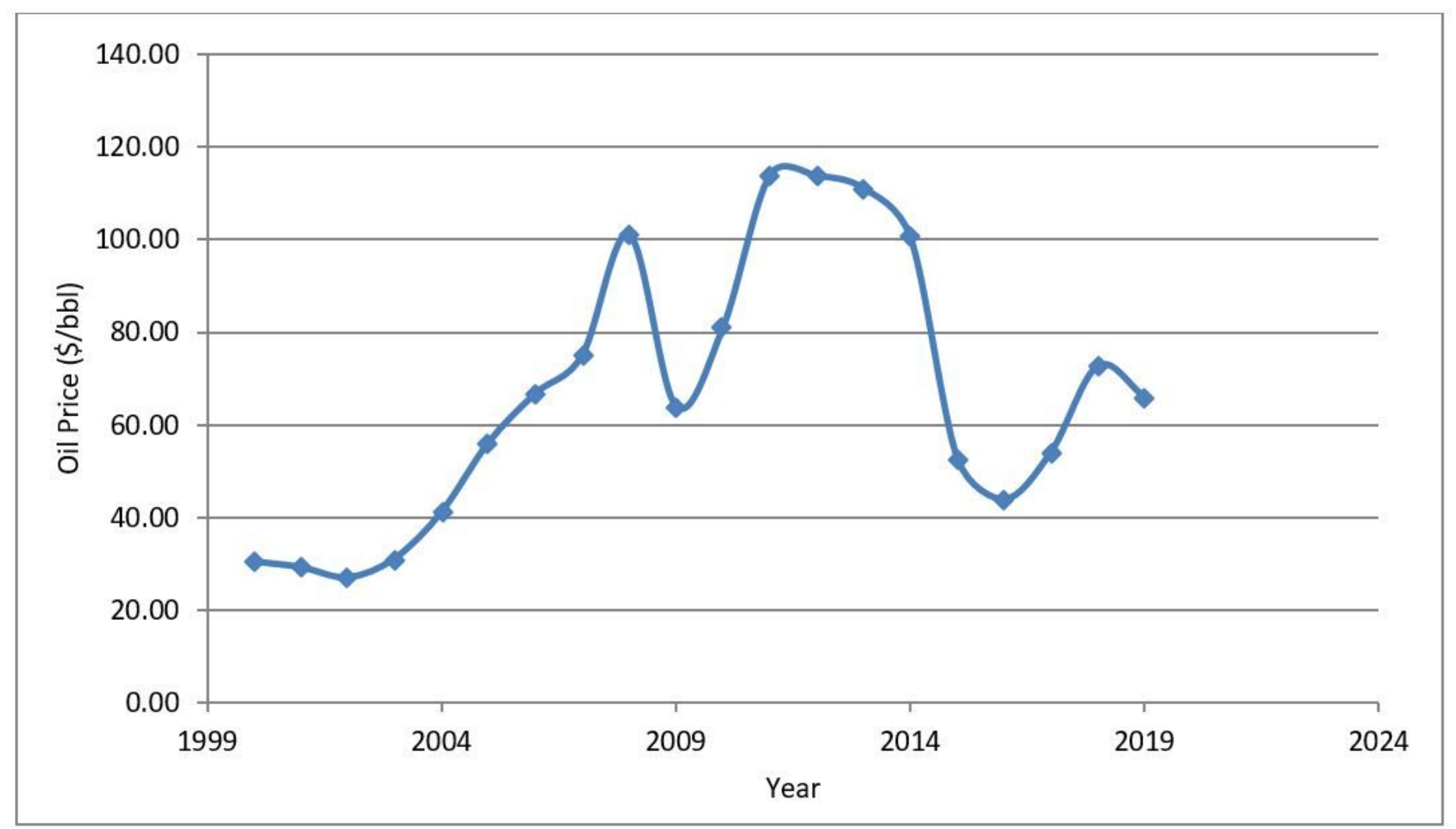

Figure 1

Oil Price for Bonny Light Crude Oil (CBN 2020; EIA 2020).

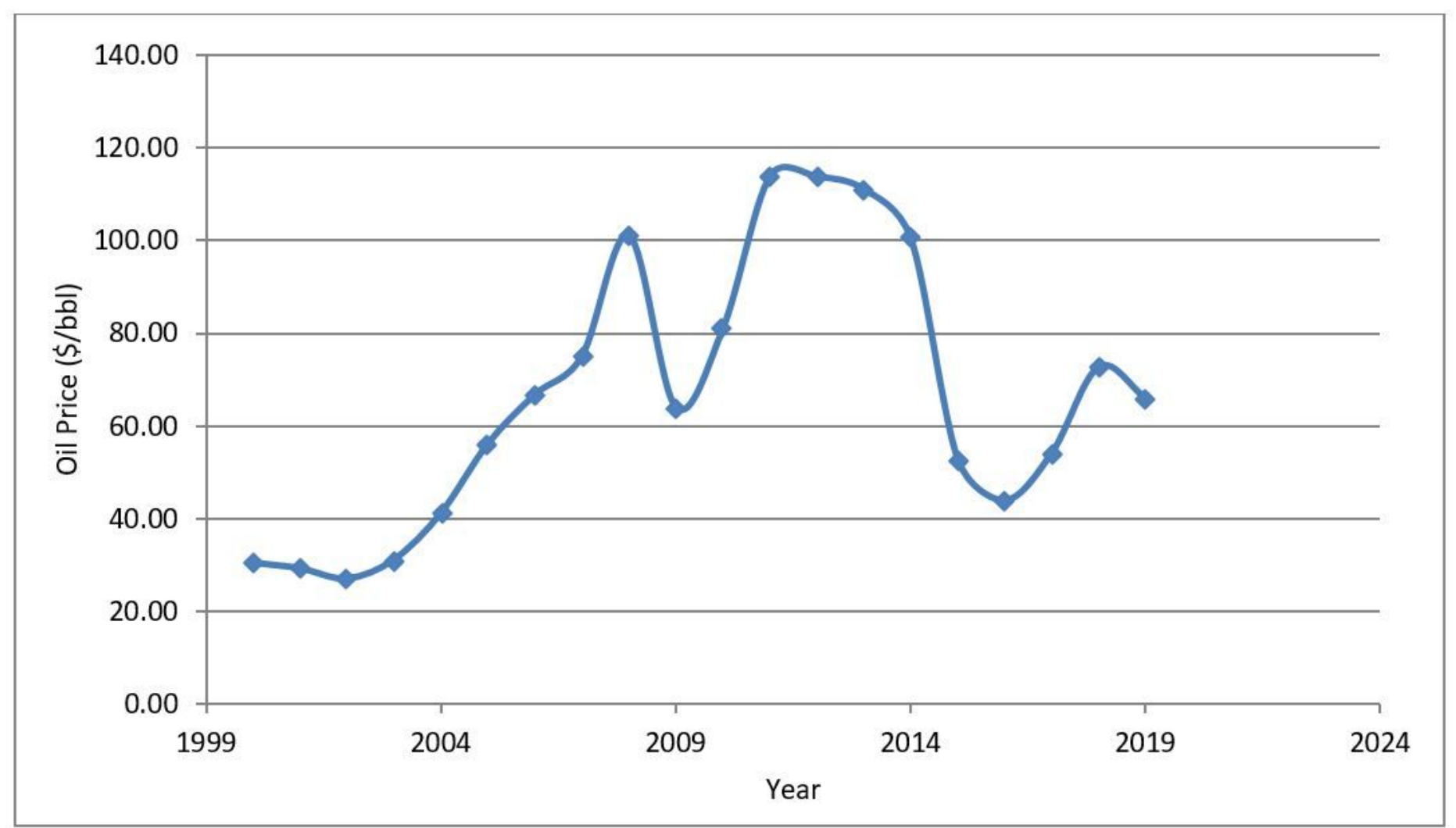


Figure 1

Oil Price for Bonny Light Crude Oil (CBN 2020; EIA 2020).

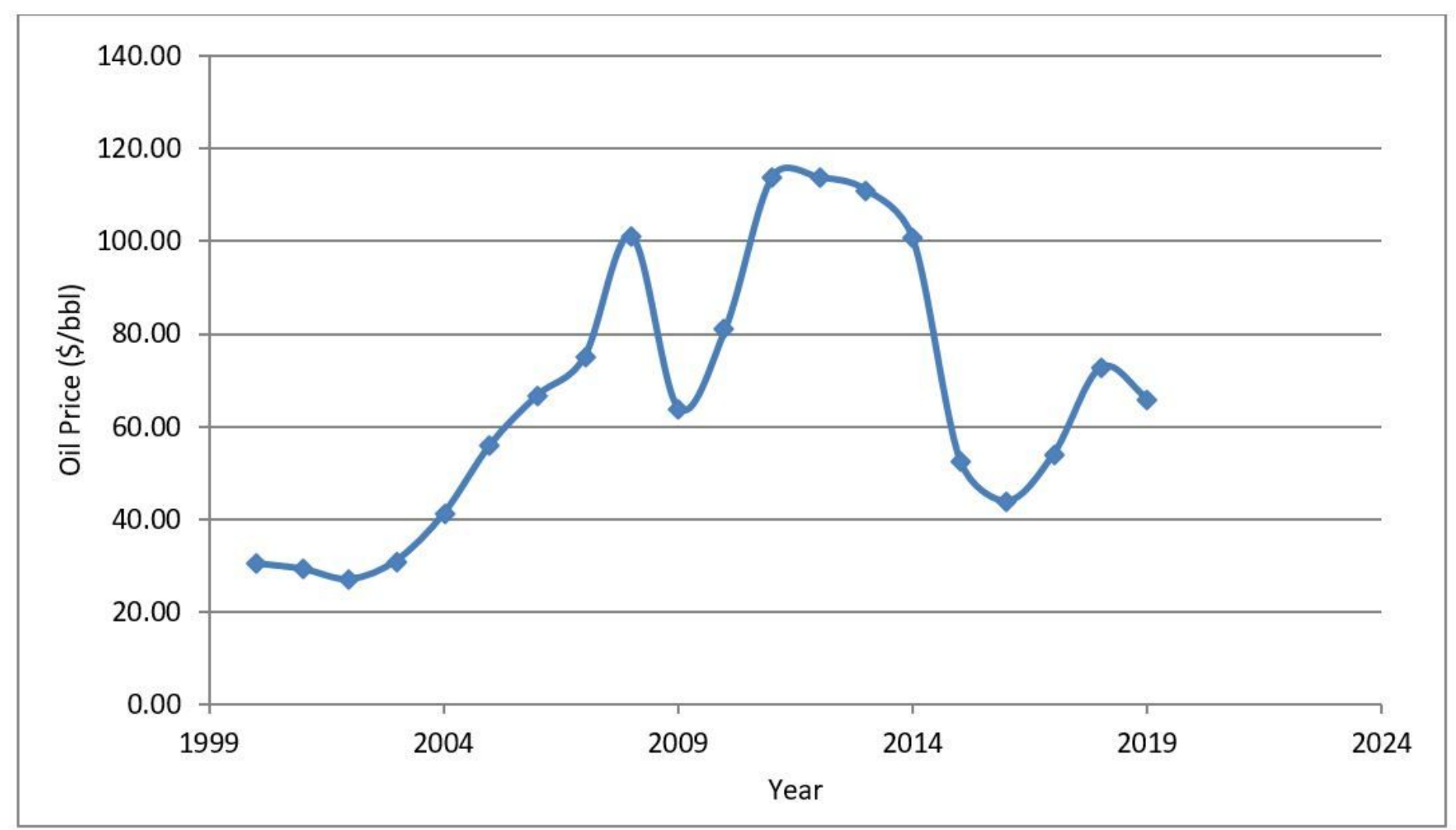

Figure 1

Oil Price for Bonny Light Crude Oil (CBN 2020; EIA 2020). 


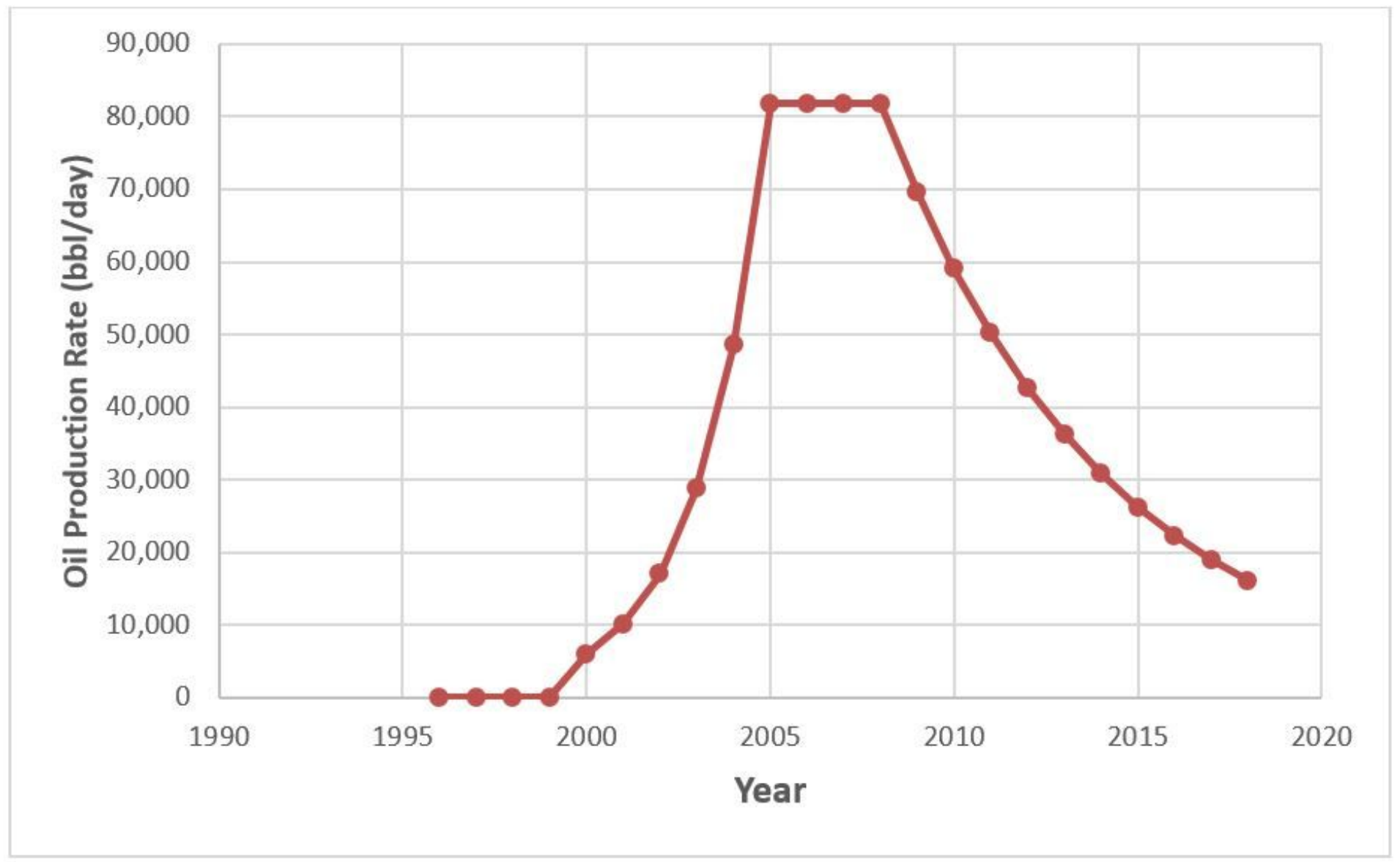

Figure 2

Production Rate of the Field 


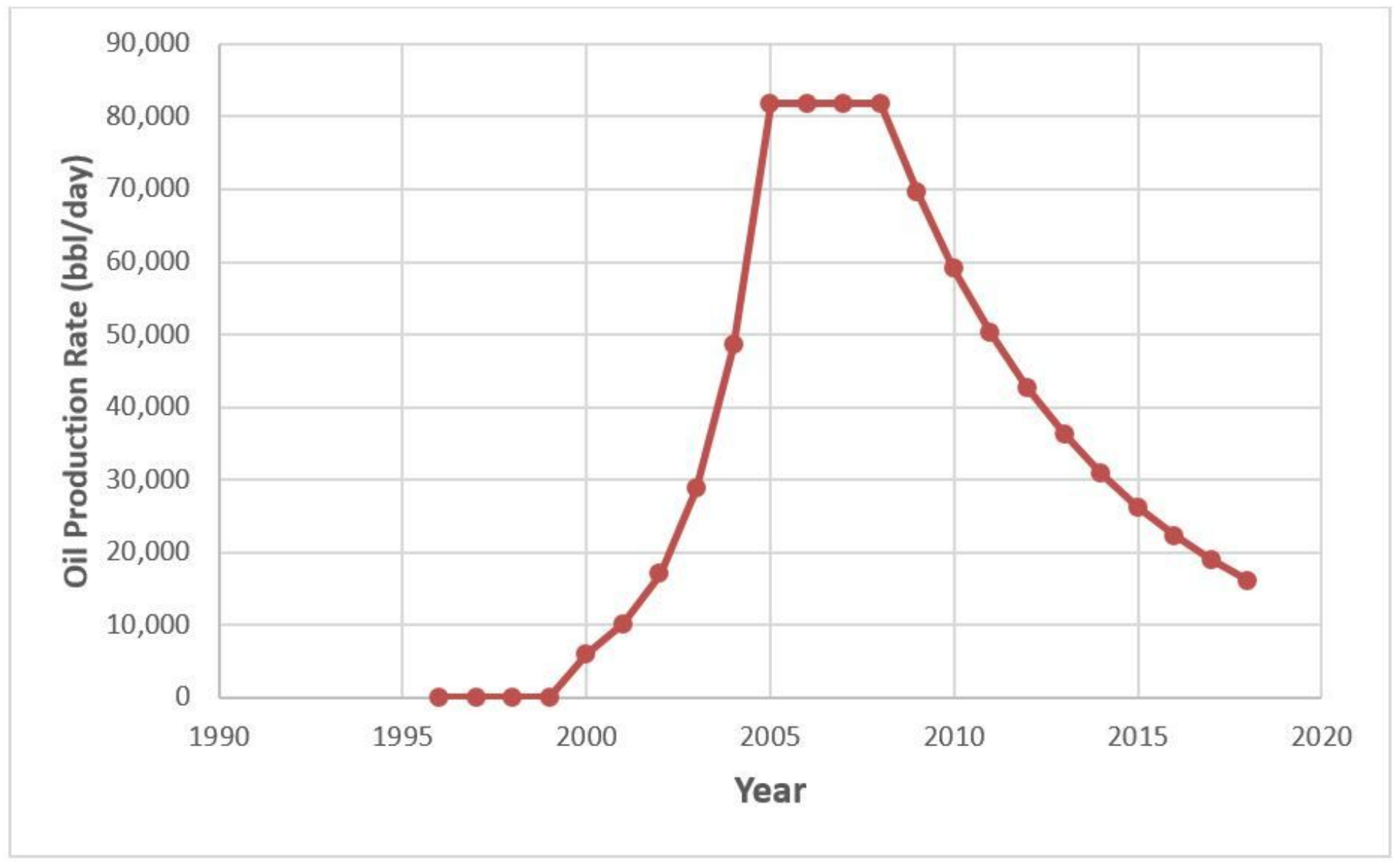

Figure 2

Production Rate of the Field 


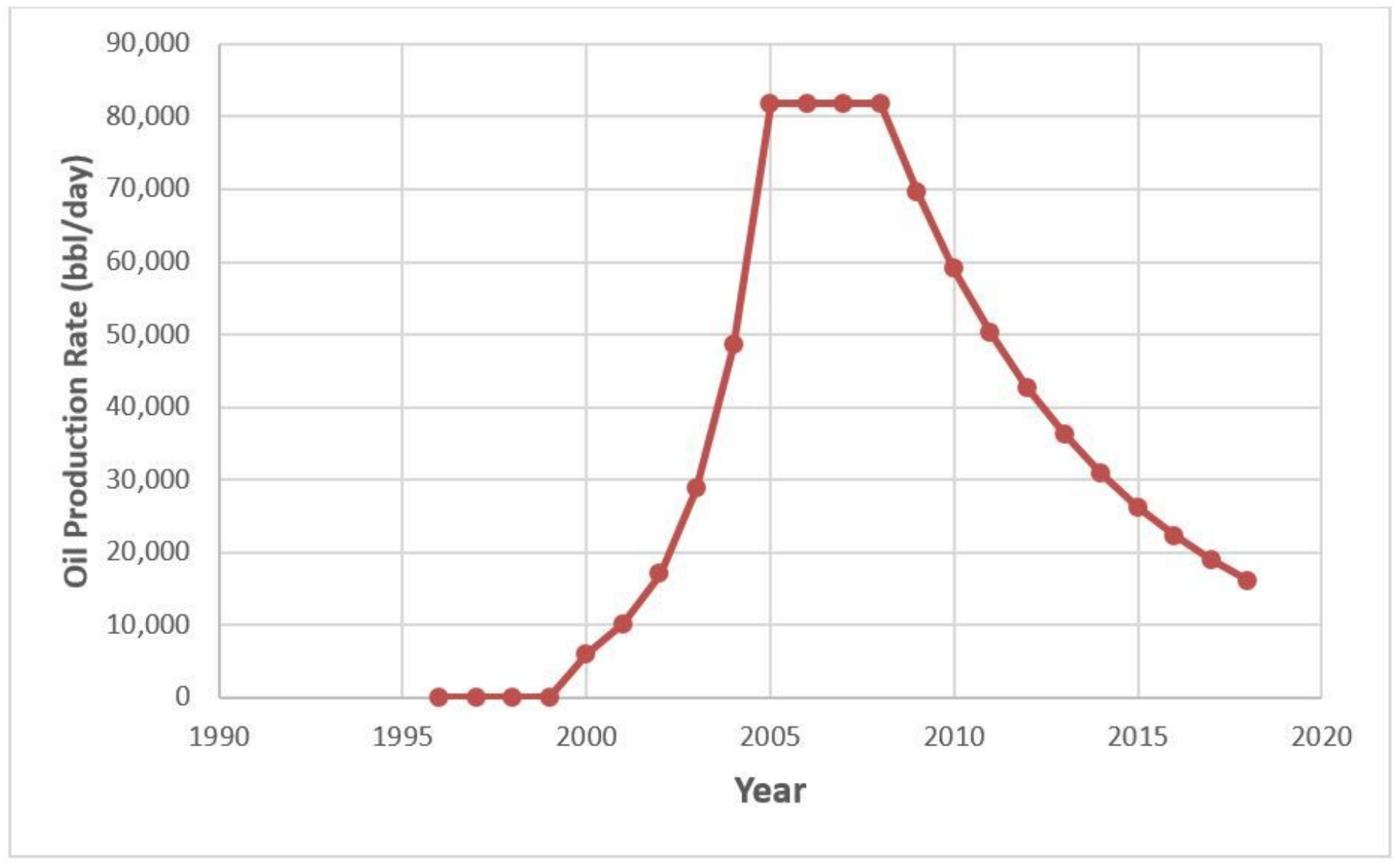

Figure 2

Production Rate of the Field 


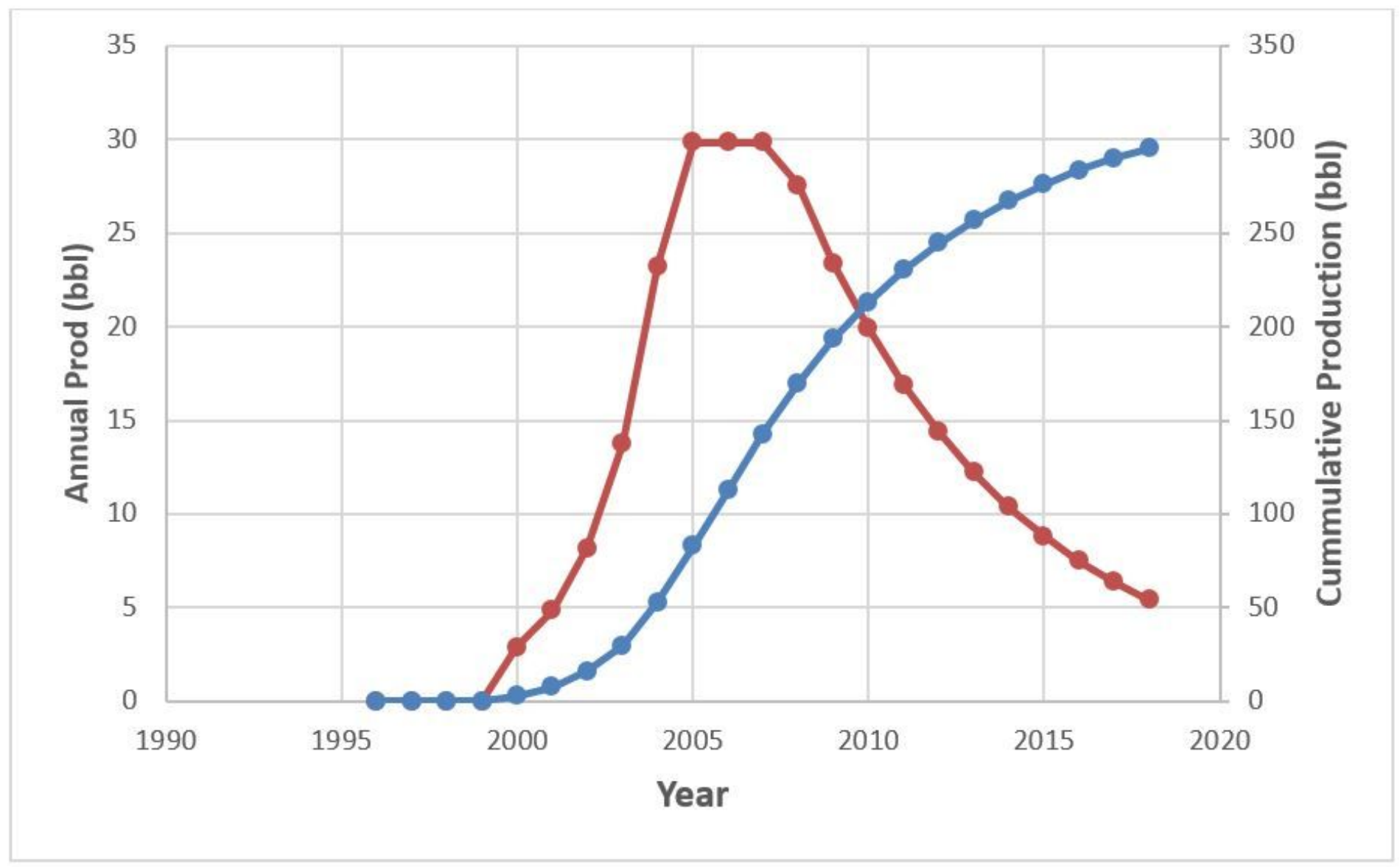

Figure 3

Annual and Cumulative Production of the Field 


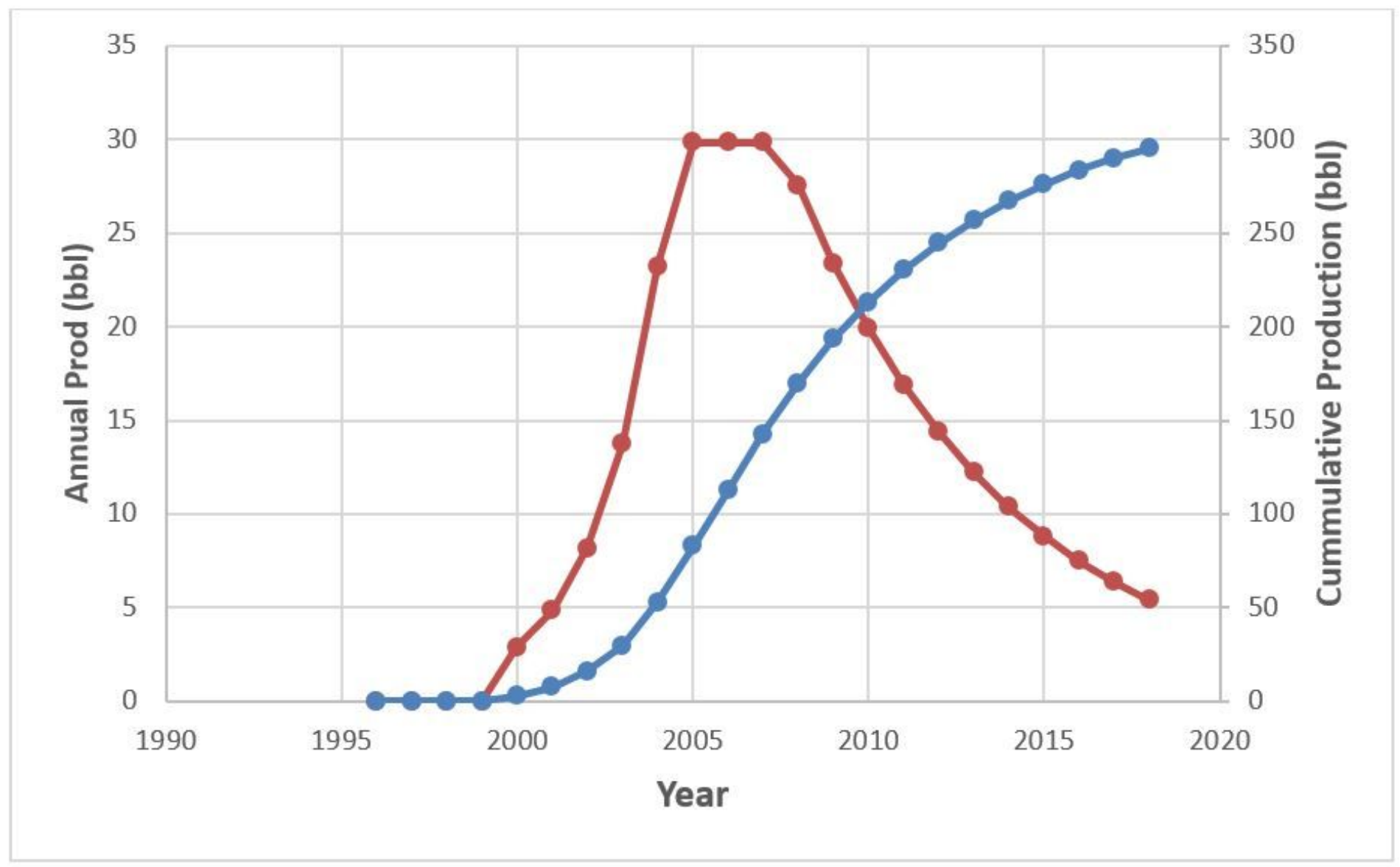

Figure 3

Annual and Cumulative Production of the Field 


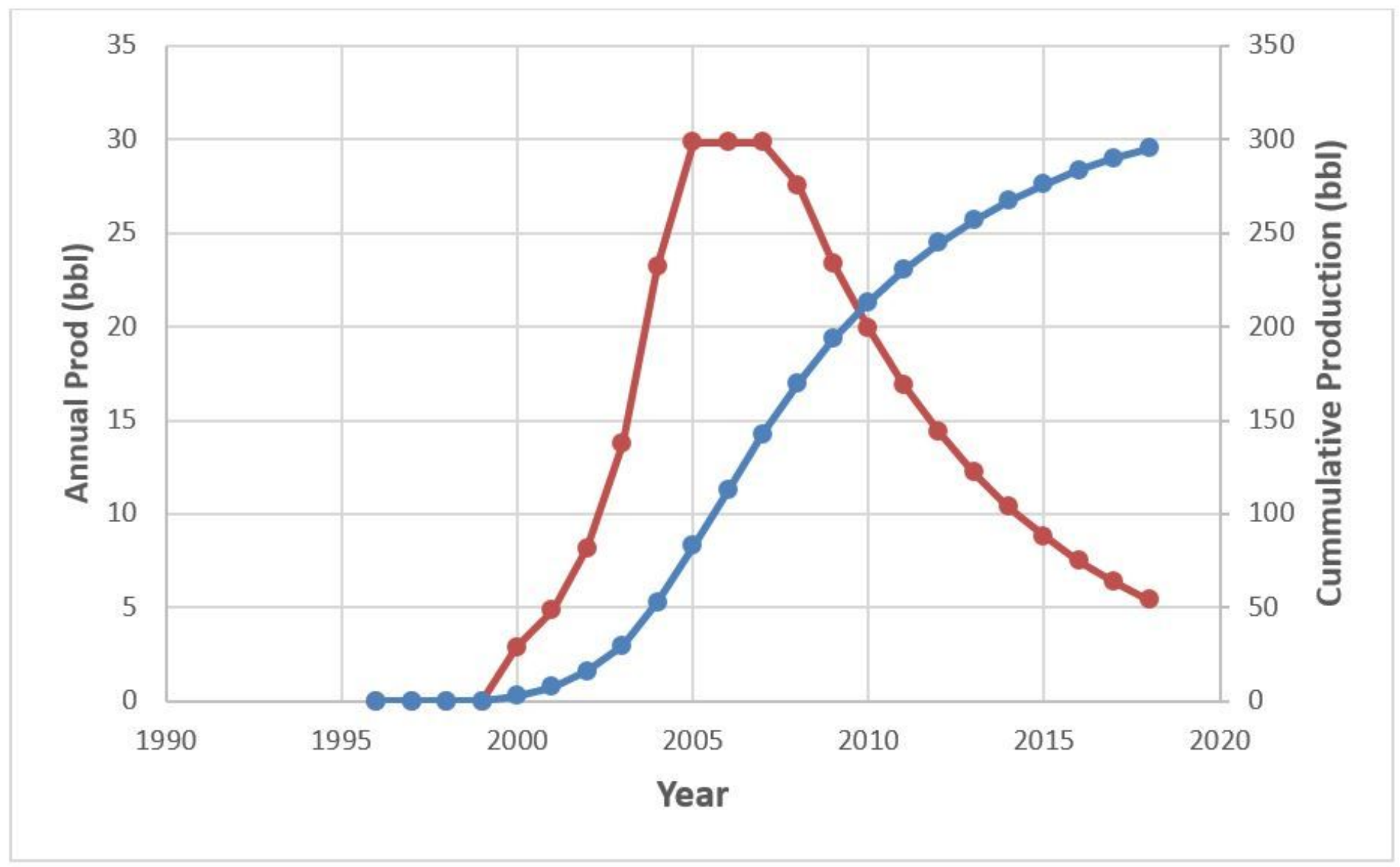

Figure 3

Annual and Cumulative Production of the Field 


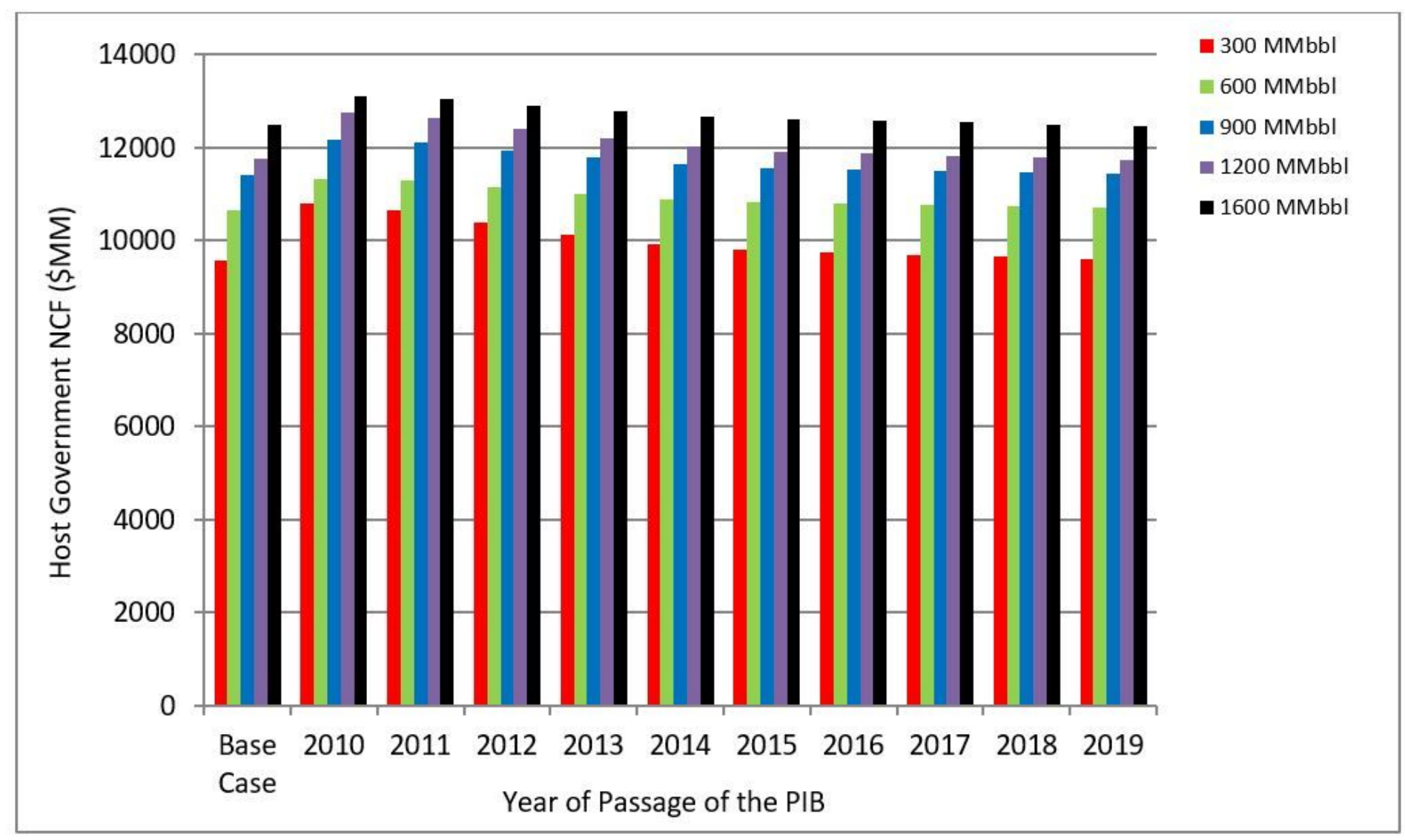

Figure 4

Host Government NCF Based on the Delay in Passing the PIB 


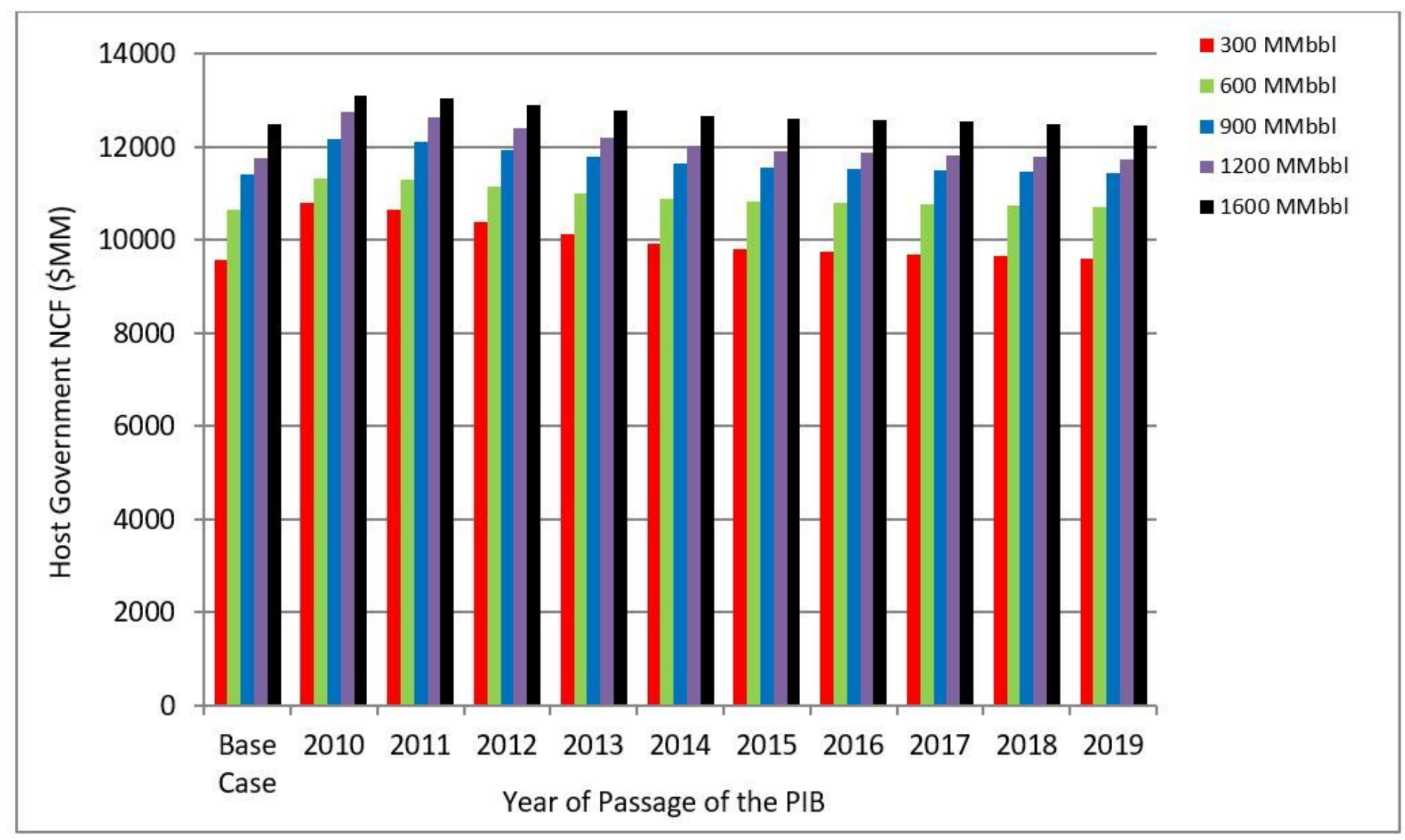

Figure 4

Host Government NCF Based on the Delay in Passing the PIB 


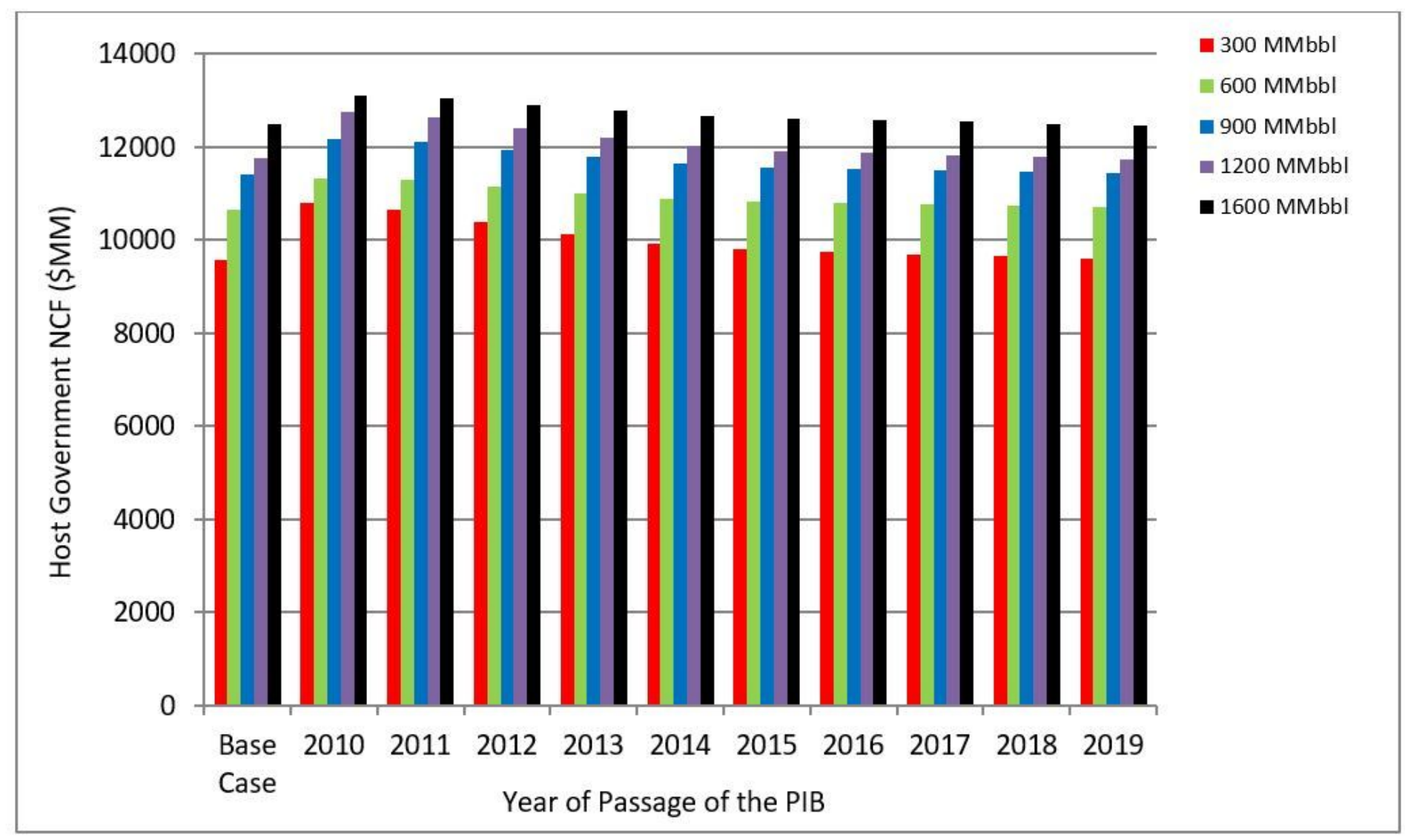

Figure 4

Host Government NCF Based on the Delay in Passing the PIB

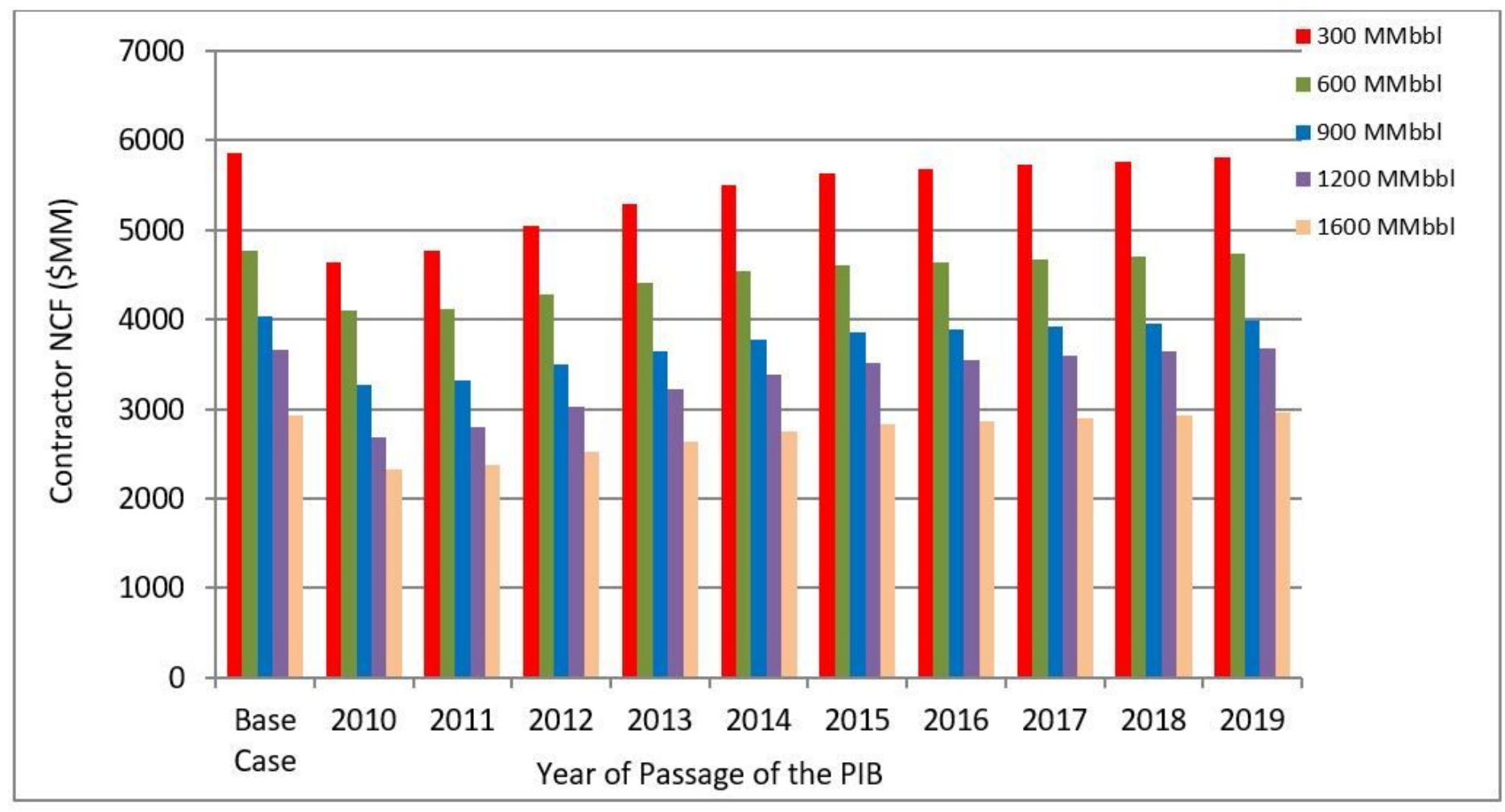


Figure 5

Contractor's NCF Based on the Delay in Passing the PIB

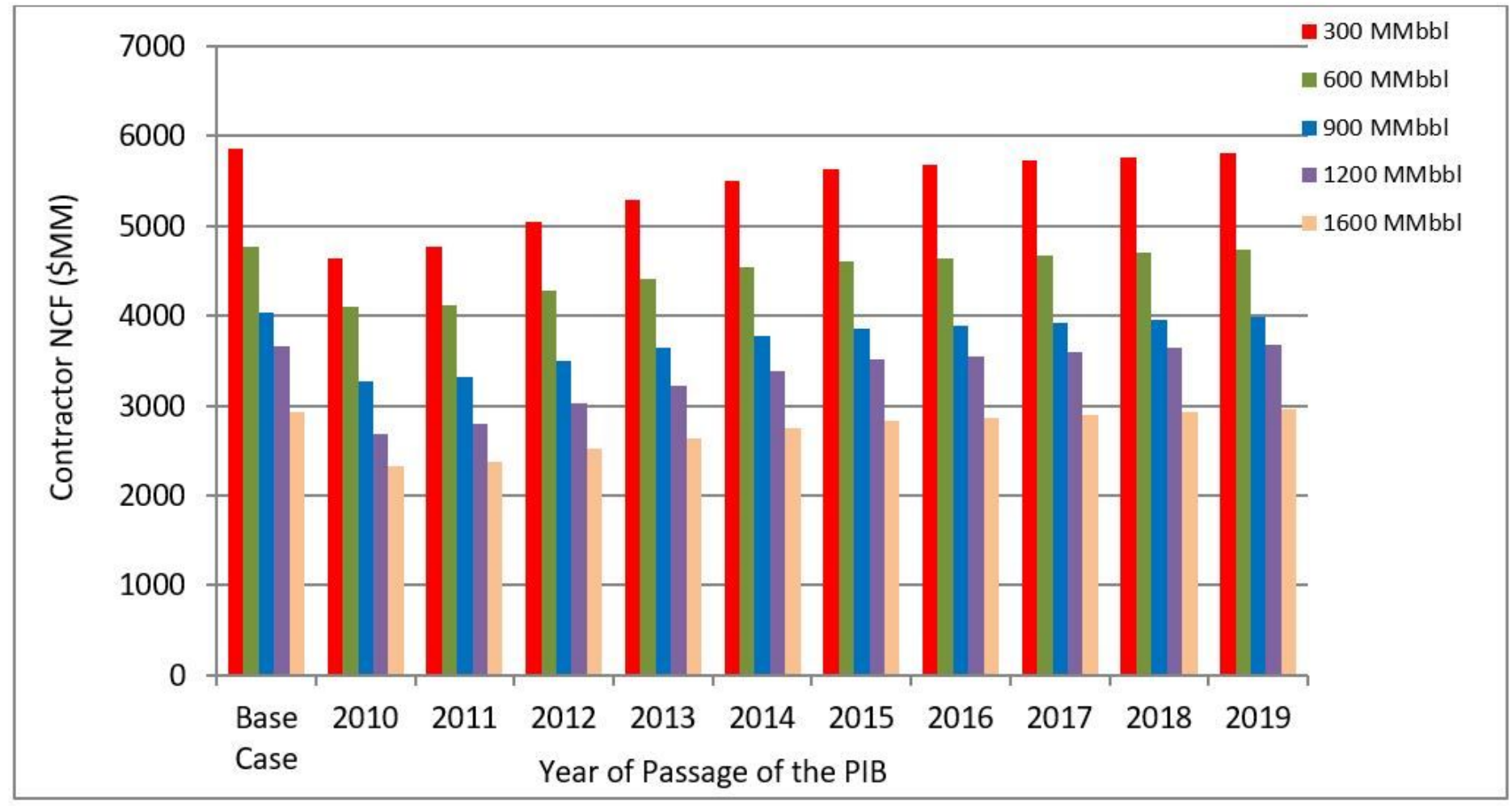

Figure 5

Contractor's NCF Based on the Delay in Passing the PIB

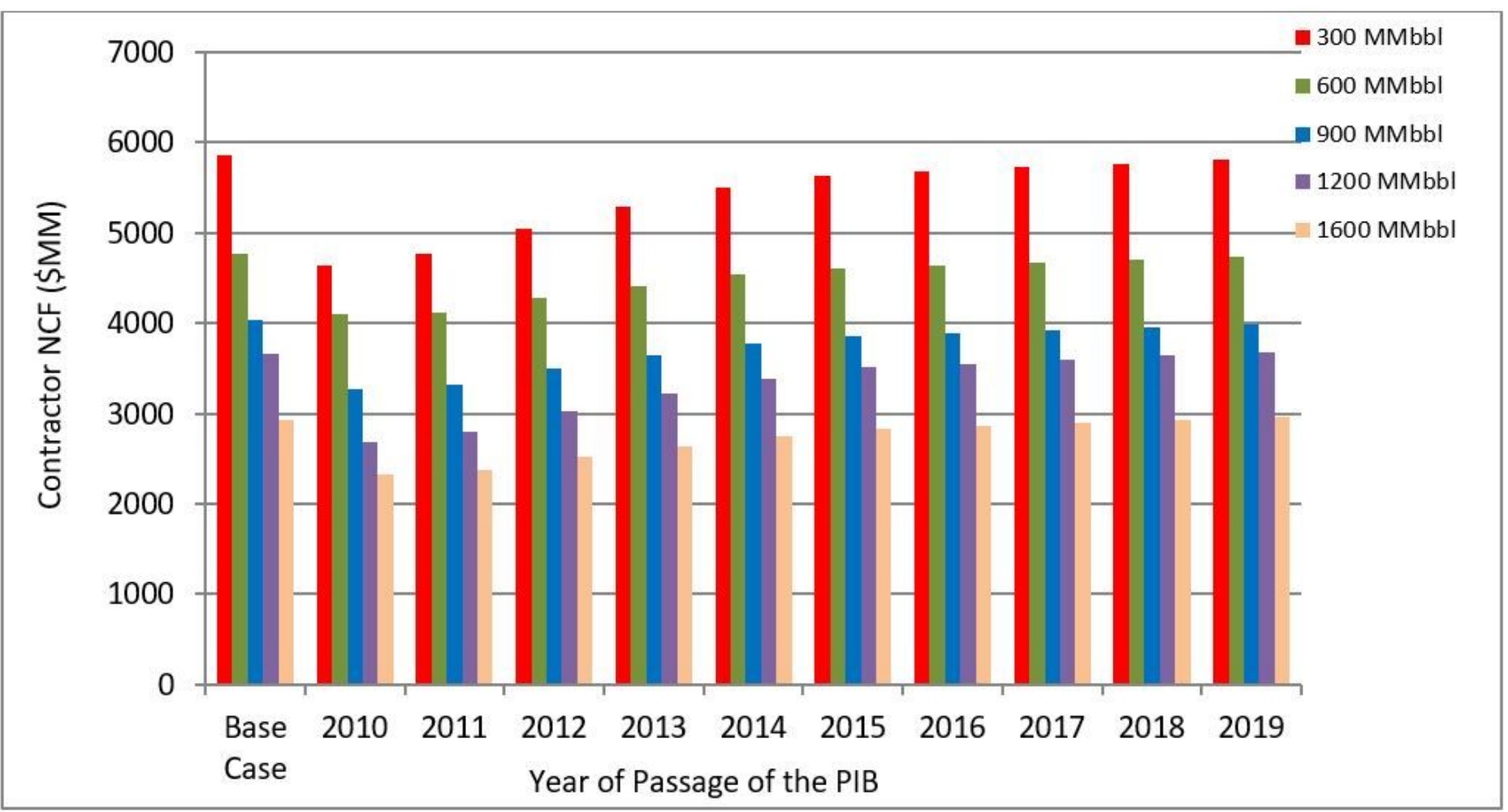


Figure 5

Contractor's NCF Based on the Delay in Passing the PIB

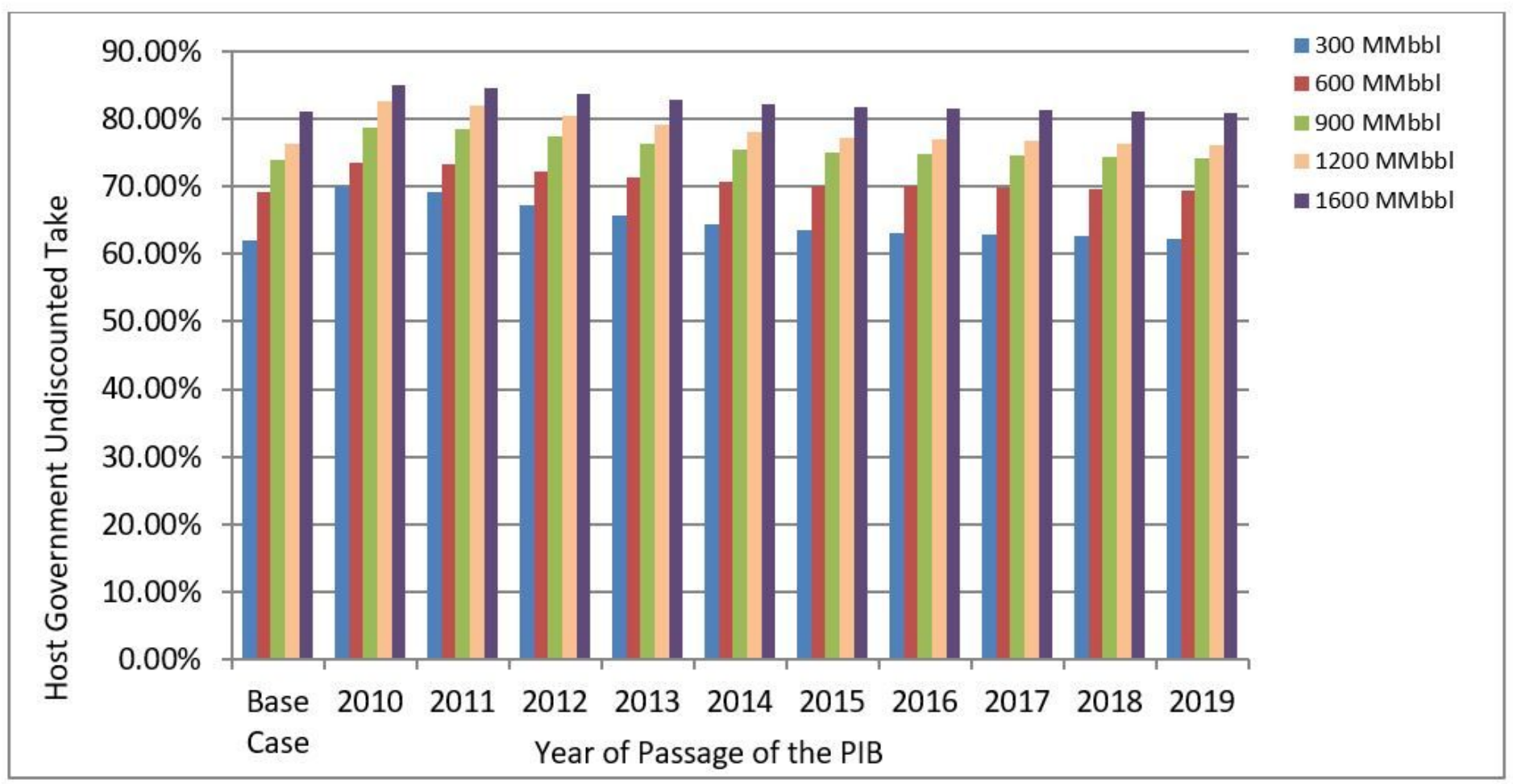

Figure 6

Host Government Undiscounted Take Based on the Delay in Passing the PIB

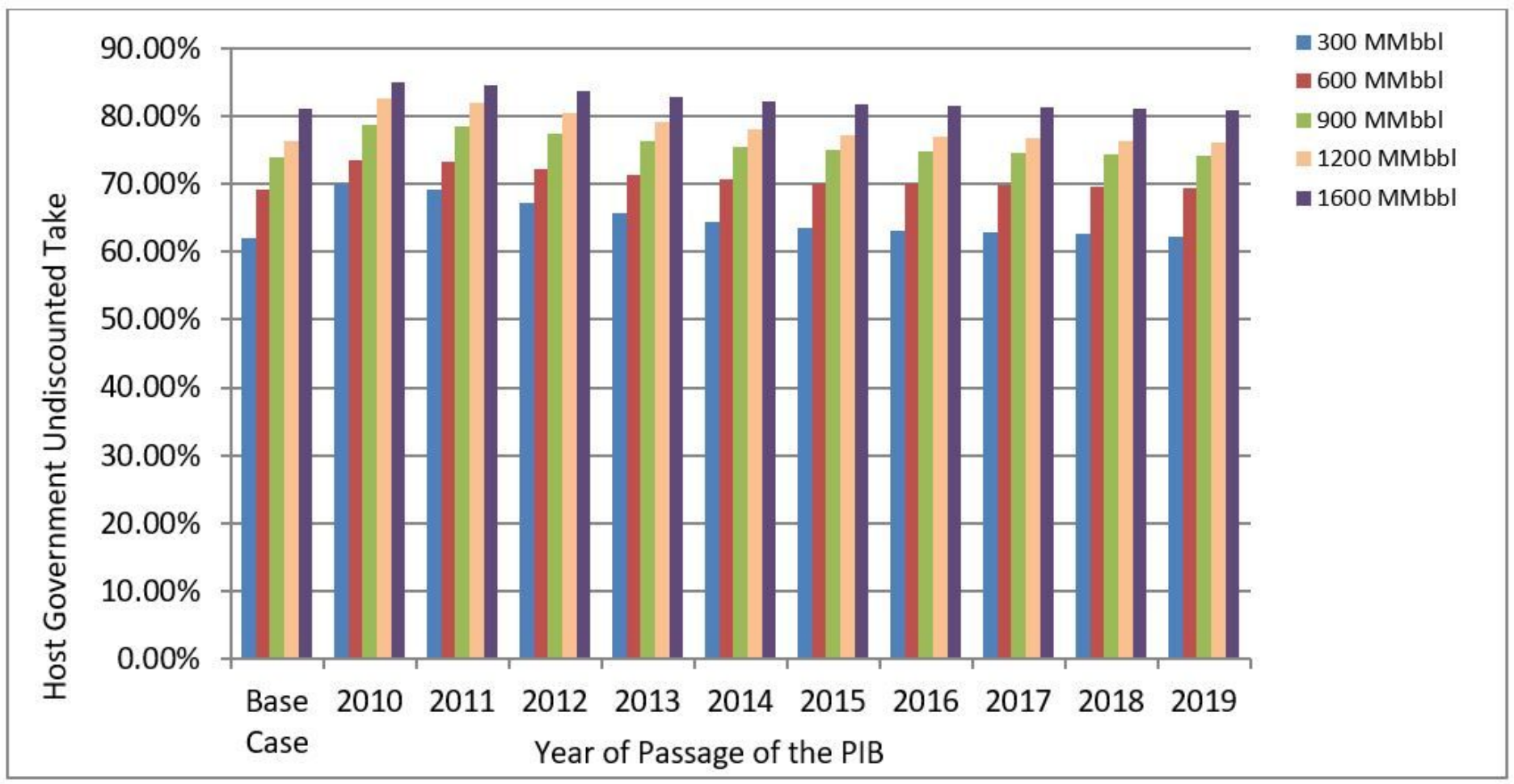


Figure 6

Host Government Undiscounted Take Based on the Delay in Passing the PIB

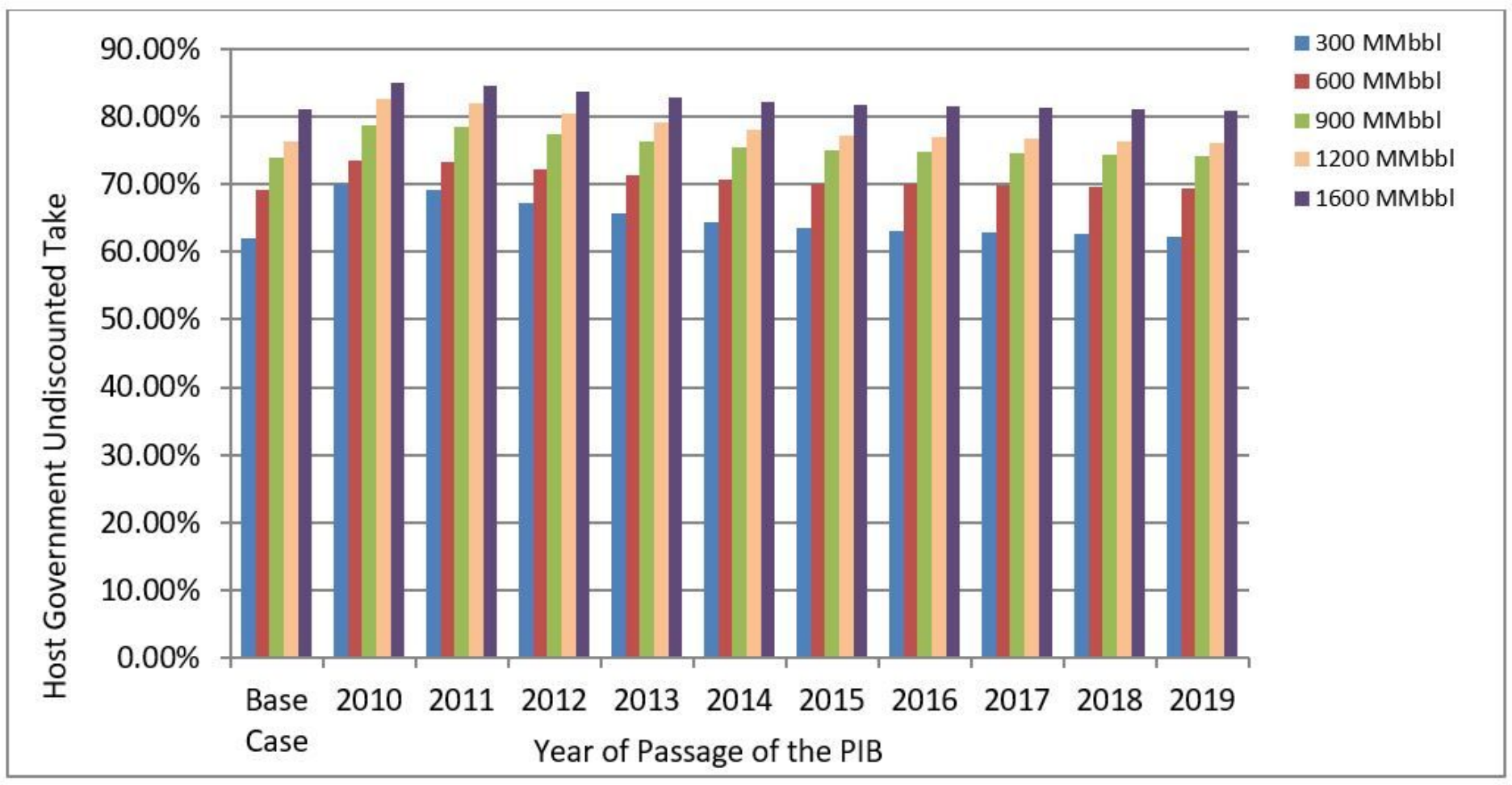

Figure 6

Host Government Undiscounted Take Based on the Delay in Passing the PIB 


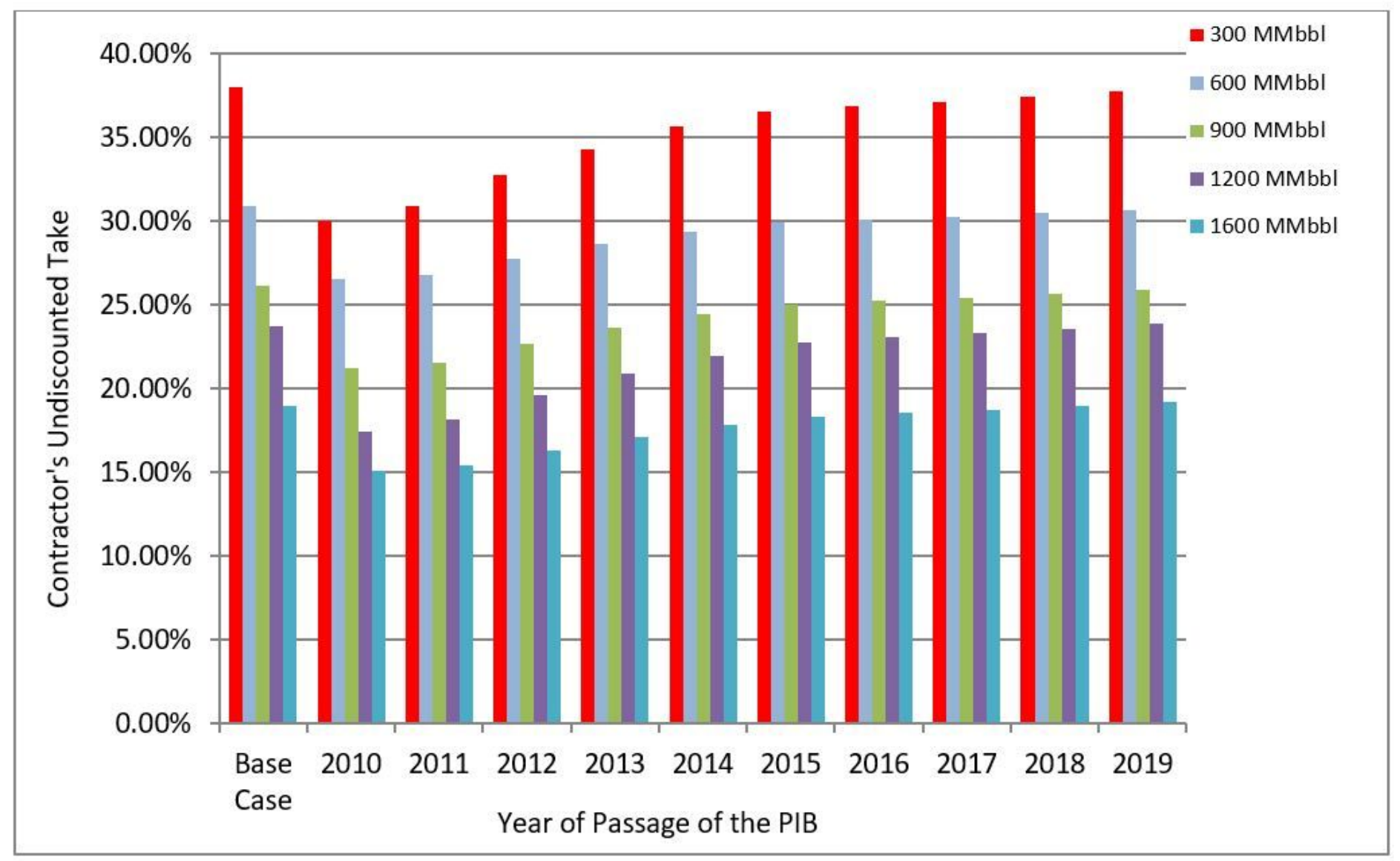

Figure 7

Contractor's Undiscounted Take Based on the Delay in Passing the PIB 


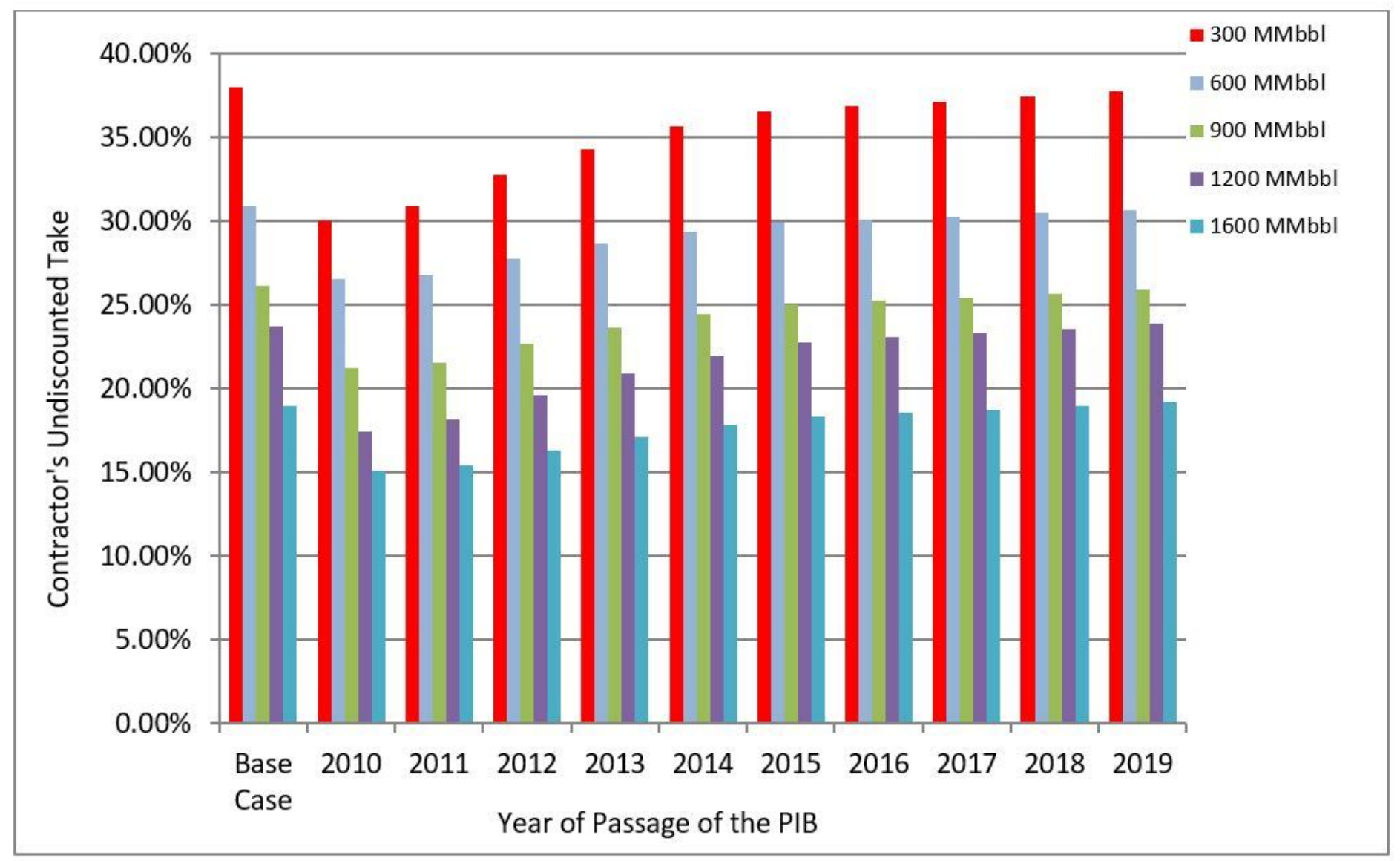

Figure 7

Contractor's Undiscounted Take Based on the Delay in Passing the PIB 


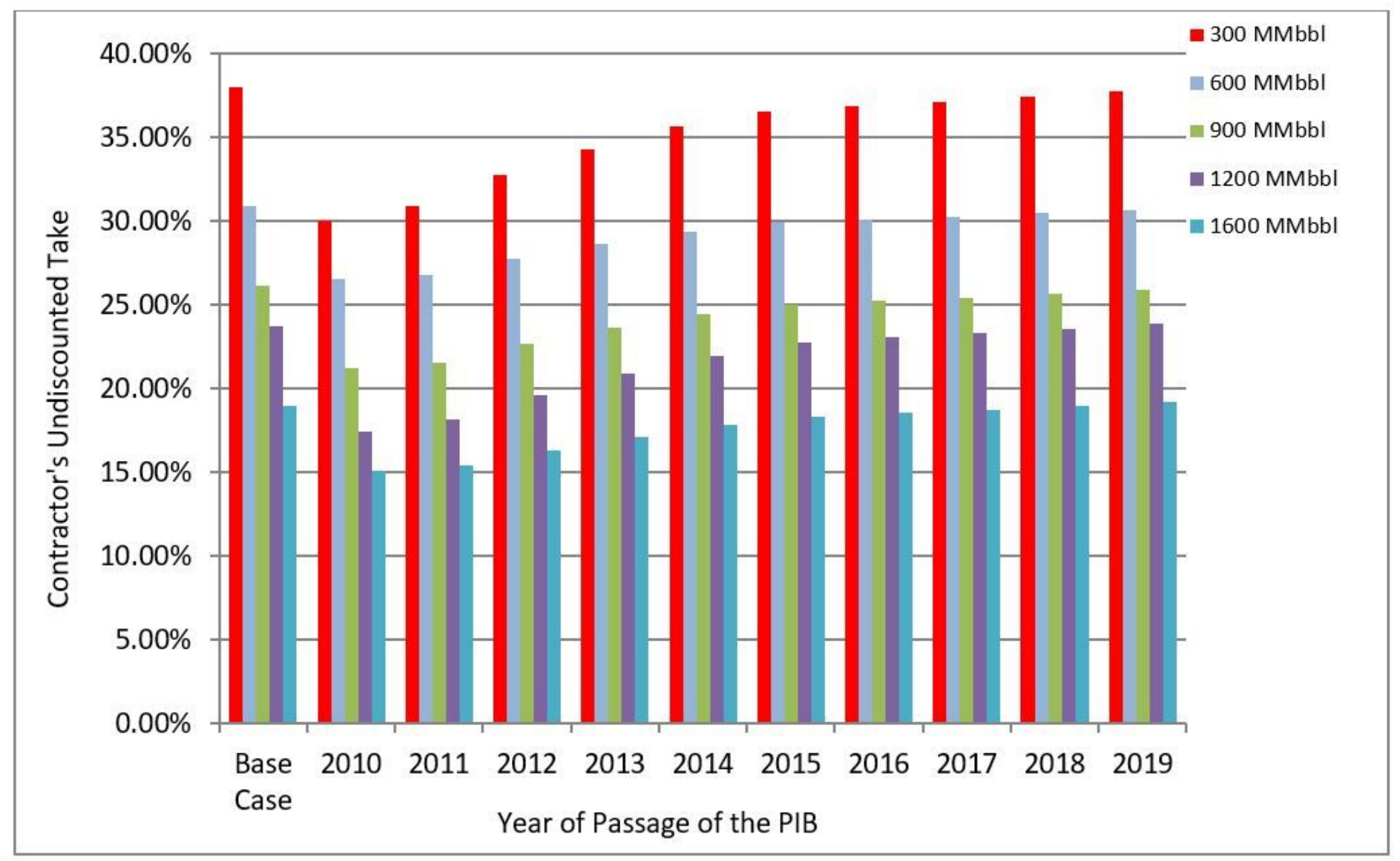

Figure 7

Contractor's Undiscounted Take Based on the Delay in Passing the PIB 


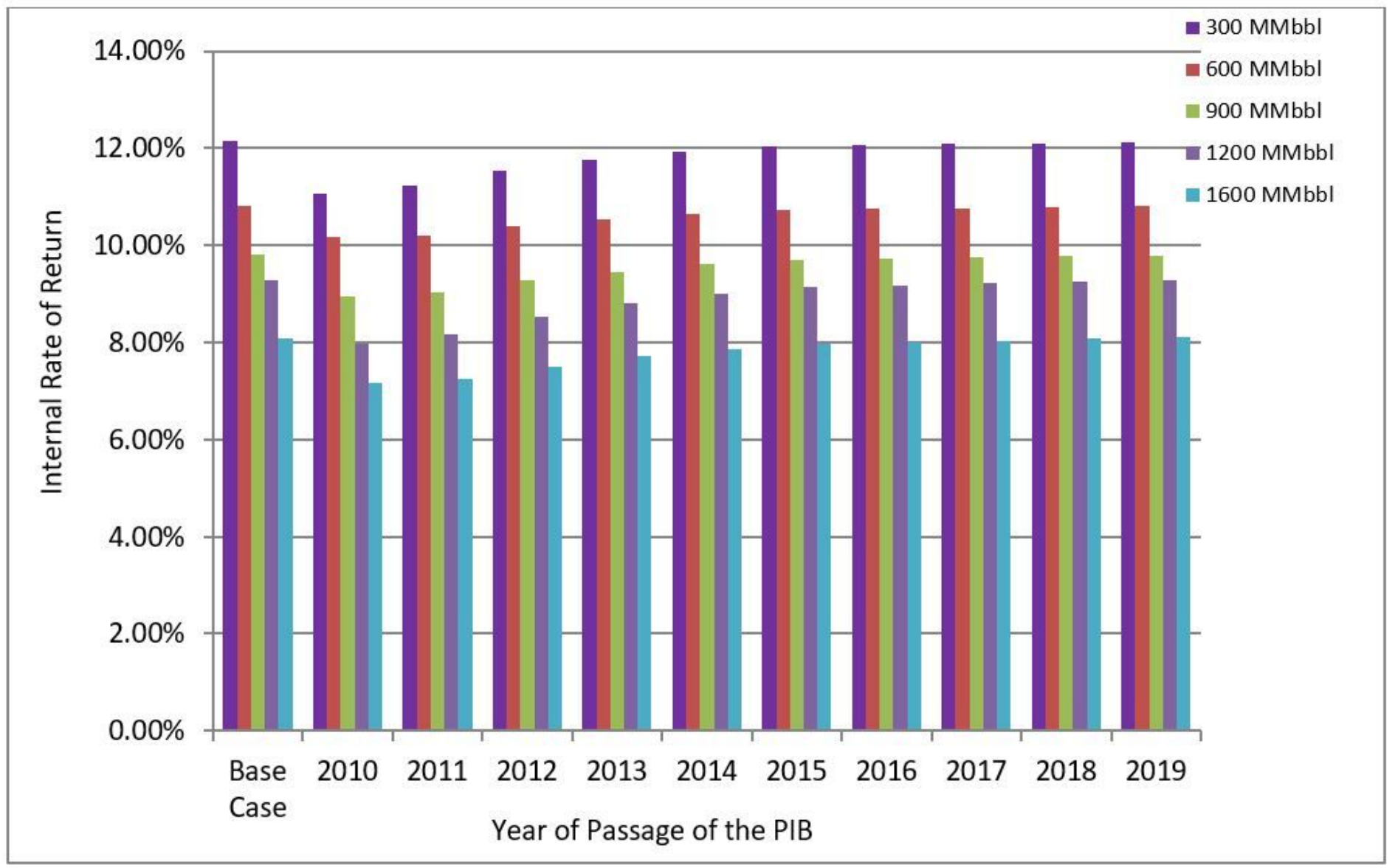

Figure 8

Internal Rate of Return Based on the Delay in Passing the PIB 


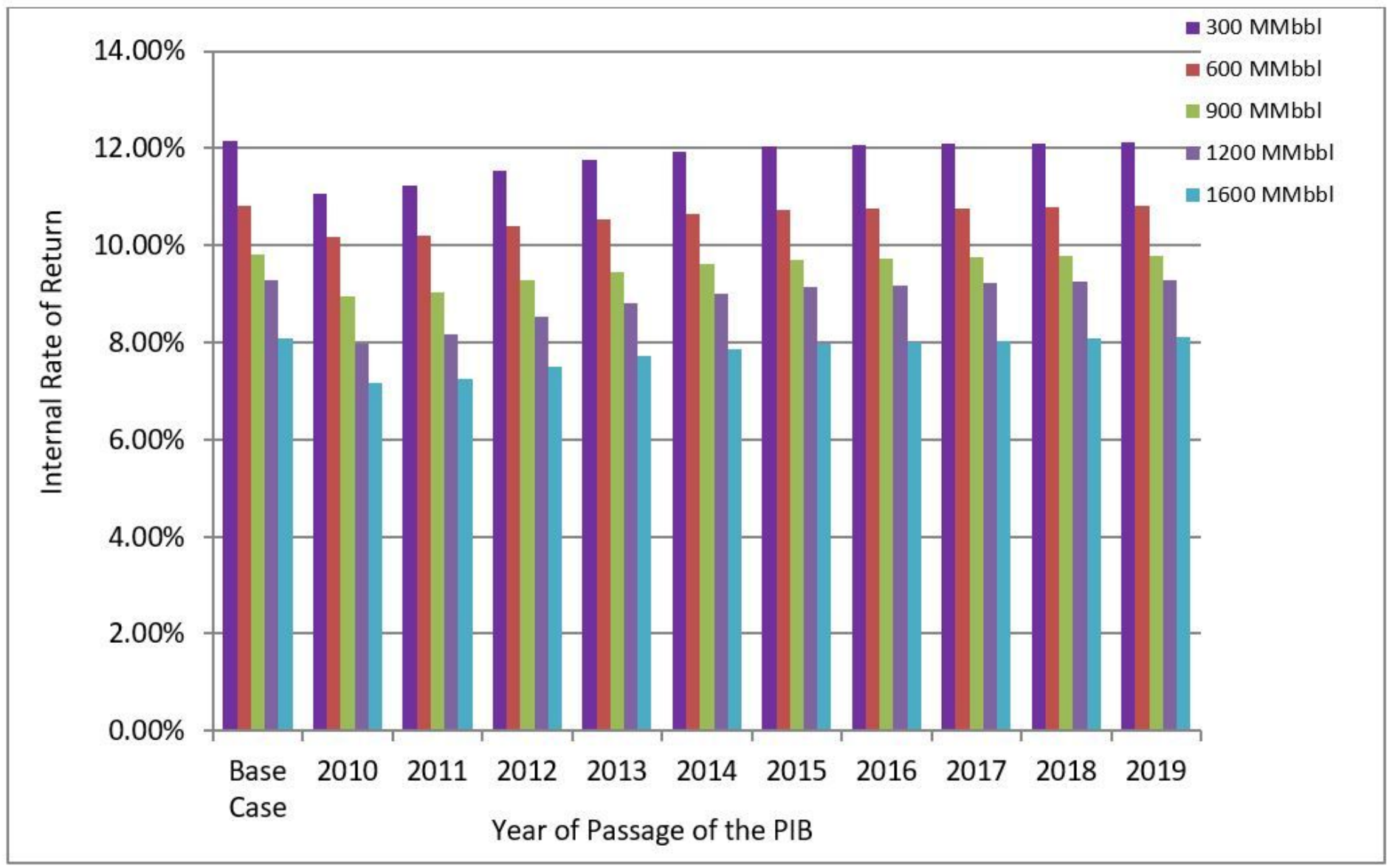

Figure 8

Internal Rate of Return Based on the Delay in Passing the PIB 


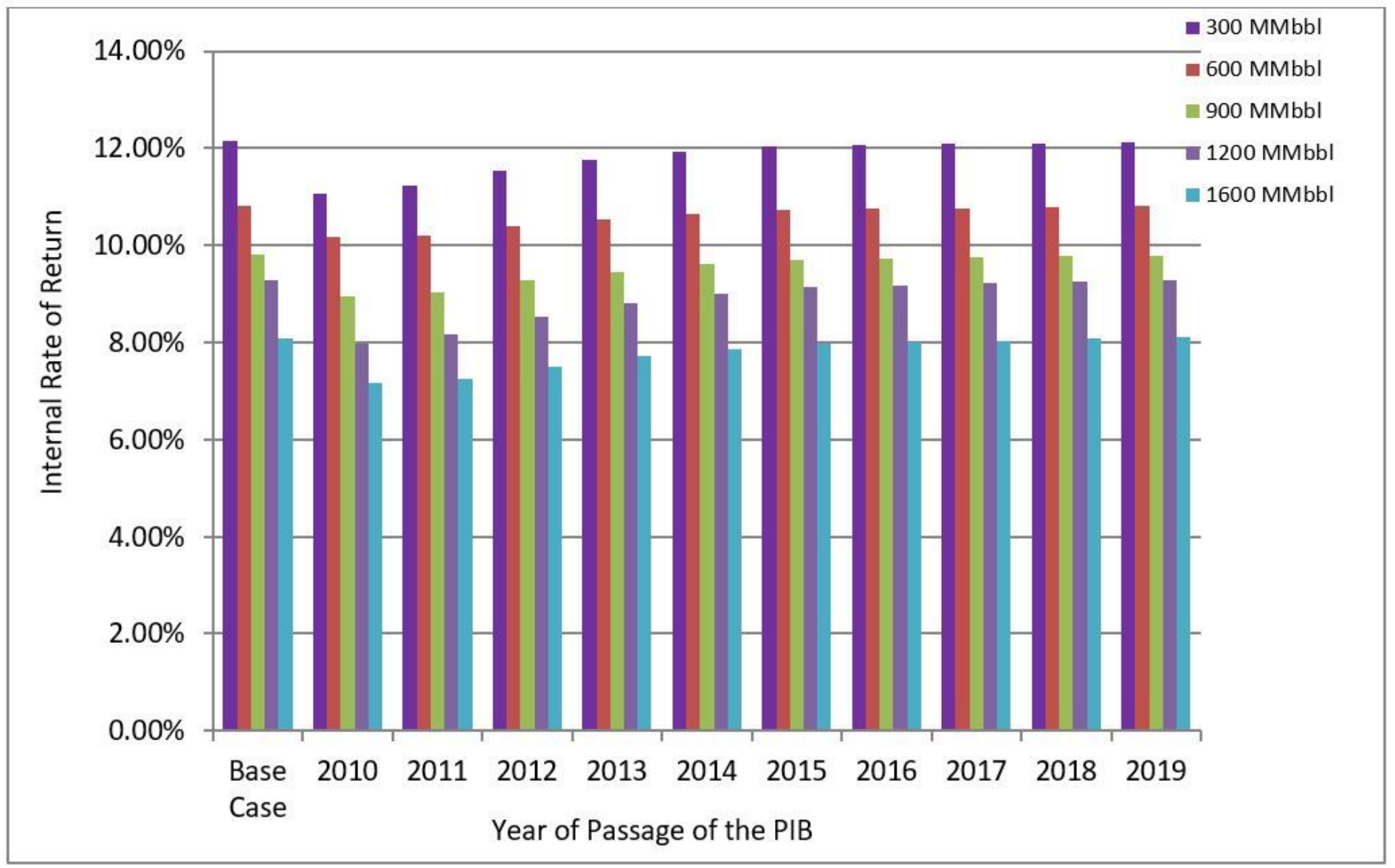

Figure 8

Internal Rate of Return Based on the Delay in Passing the PIB 